Article

\title{
Long-Term Assessment of Onshore and Offshore Wind Energy Potentials of Qatar
}

\author{
Valliyil Mohammed Aboobacker ${ }^{1}$ (D), Puthuveetil Razak Shanas ${ }^{2}$, Subramanian Veerasingam ${ }^{1}$ (D), \\ Ebrahim M. A. S. Al-Ansari ${ }^{1}$, Fadhil N. Sadooni ${ }^{1}$ (D) and Ponnumony Vethamony ${ }^{1, *(D)}$ \\ 1 Environmental Science Center, Qatar University, Doha 2713, Qatar; vmaboobacker@qu.edu.qa (V.M.A.); \\ v.subramanian@qu.edu.qa (S.V.); isalansari@qu.edu.qa (E.M.A.S.A.-A.); fsadooni@qu.edu.qa (F.N.S.) \\ 2 CSIR-National Institute of Oceanography, Dona Paula, Goa 403 004, India; shanaspr@nio.org \\ * Correspondence: pvethamony@qu.edu.qa
}

Citation: Aboobacker, V.M.; Shanas, P.R.; Veerasingam, S.; Al-Ansari, E.M.A.S.; Sadooni, F.N.; Vethamony P. Long-Term Assessment of Onshore and Offshore Wind Energy Potentials of Qatar. Energies 2021, 14, 1178.

https://dx.doi.org/10.3390/en14041178

Received: 13 October 2020

Accepted: 6 November 2020

Published: 23 February 2021

Publisher's Note: MDPI stays neutral with regard to jurisdictional claims in published maps and institutional affiliations.

Copyright: () 2021 by the authors. Licensee MDPI, Basel, Switzerland. This article is an open access article distributed under the terms and conditions of the Creative Commons Attribution (CC BY) license (https: / / creativecommons.org / licenses/by/4.0/).

\begin{abstract}
Exploitation of conventional energy resources has caused a deliberate increase in the emitted carbon in the atmosphere, which catalyzes global warming trends. This is a matter of concern, especially in Qatar, where fossil fuels (oil and gas) are largely relied upon for power production. The dependency on such resources could be gradually reduced by utilizing clean and renewable energy. Resource characterization is an important step to evaluate the potentiality of available renewable energy sources. Wind energy is one among them, which has not been assessed reliably so far in Qatar. We analyzed the wind energy potential along the onshore and offshore areas of Qatar using 40 years (1979-2018) of hourly wind data extracted from the ECMWF Reanalysis v5 (ERA5) database. Monthly, seasonal, annual, and decadal mean wind power densities have been derived. Reliability tests have been carried out at select onshore and offshore locations. Trends and inter-annual variability have been assessed. The study reveals that the available wind resources are generally moderate but consistent with no intense trends during the 40 year period. An inter-annual variability in wind power has been identified, which has secured links with the El Niño-Southern Oscillation (ENSO).
\end{abstract}

Keywords: wind energy; ERA5 reanalysis winds; shamal winds; ENSO; Qatar coast

\section{Introduction}

Conventional energy resources have been largely exploited worldwide [1]. The environmental impact due to carbon emission is one of the major concerns when utilizing such resources [2]. In addition, fuel/oil resources are gradually depleting on account of exploitation/over-exploitation [3]. An emerging trend is the utilization of nonconventional energy resources such as solar, wind, tides, and waves, which are clean and renewable [4]. Electricity production in the United States from renewable sources surpassed coal in April 2019 (https:/ / www.eia.gov/todayinenergy/detail.php? $\mathrm{id}=39992)$. Wind power is the second-most widely used renewable energy source in the world after hydropower, accounting for $24 \%$ of the world's electricity generation capacity (https: / / www.power-technology.com/features/). Wind power can be exploited both onshore and offshore. The utilization of wind power is subject to its potentiality in addition to the demand, economy, and policies. The wind energy potential has been analyzed and implemented at a few locations around the globe. A few examples are presented here. China holds the biggest wind energy generation capacity in the world with a production of more than 211 GW in 2018 (https:/ / www.nsenergybusiness.com/features / china-wind-power-asia-pacific/). The total installed wind power capacity in the United States is around 105 GW (https: / / windexchange.energy.gov/maps-data/321). The onshore and offshore wind power capacities in the UK are around 13.6 and $8.4 \mathrm{GW}$, respectively (https: / / www.renewableuk.com). The wind power capacity from installations in India is around 4.6 GW [5]. 
Accurate assessment of wind energy potential is a pre-requisite for planning and execution of wind power generation. Measured, satellite, or re-analysis winds are commonly used for such an assessment [6,7]. Long-term hindcast/forecast winds from global re-analysis products are considered reliable sources for wind power assessment [8], and adequate enough when the measured or satellite observations are sparse in a particular region. A few examples of such winds are: Climate Forecast System Reanalysis (CFSR) $[9,10]$, Modern-Era Retrospective Analysis for Research and Applications, Version 2 (MERRA2) [11], and European Centre for Medium-Range Weather Forecasts (ECMWF) Reanalysis (ERA) products such as ERA40 [12], ERA-Interim [13], and ERA5 [14]. These re-analysis wind data are subject to statistical corrections by assimilating extensive sets of in situ and scatterometer winds into their model outputs [15]. In addition, site-specific validations are commonly carried out prior to wind power assessments. The ERA5 is the latest update of the ERA series, which has been used in wind climate and wind power assessments [16-19]; ERA5 winds have lower uncertainty and minimal errors than the other reanalysis winds when compared with measurements [20,21].

A better understanding of wind climate in a particular region is essential in prejudicing the feasibility of a resource assessment. In this study, our focus is on the onshore and offshore regions of Qatar (Figure 1), situated on the central Arabian/Persian Gulf (hereafter called "Gulf"). The predominant winds over the Gulf are northwesterlies throughout the year [22], and often dominated by shamal winds [23,24]. The shamal winds are the stronger northwesterly or northerly wind events, which occur during summer and winter [25]. Southerly or southeasterly winds are often found in the Gulf, especially during winter [22]. The shamal wind speeds in the northern Gulf are higher during summer than winter, while the central and southern Gulf experience the opposite [26]. The winter mean wind speed is higher in the central Gulf, of the order of $5.9 \mathrm{~m} / \mathrm{s}$, whereas the summer mean wind speed is higher in the northern Gulf, of the order of $4.9 \mathrm{~m} / \mathrm{s}$. The variability in wind speed is high in the southern/eastern Gulf followed by the central Gulf and the northern Gulf. The wind variability in Qatar is composed of regional wind systems, as well as the sea/land-breezes [27]. The sea/land-breezes prevail only when the regional wind systems weaken, and it is more pronounced during summer than winter [28]. The wind direction is predominantly northwest and north-northwest in Qatar. The annual mean wind speed varies between 3.0 and $5.0 \mathrm{~m} / \mathrm{s}$, whereas the 95th percentile wind speed is between 8.0 and $12.0 \mathrm{~m} / \mathrm{s}$ [29].

Wind energy resources were assessed worldwide. A few examples from the adjacent regions are: Mediterranean Sea (100-500 W/m $\mathrm{m}^{2}$ ) [30-32], terrestrial area of Turkey (50$100 \mathrm{~W} / \mathrm{m}^{2}$ ) [33], Arabian Peninsula (50-200 W/m²) [34], and Kuwait (100-300 W/m²) [35]. Wind energy potential was found to be moderate $\left(180 \mathrm{~W} / \mathrm{m}^{2}\right)$ to high $\left(>400 \mathrm{~W} / \mathrm{m}^{2}\right)$ along the Egyptian coast at different stations, calculated at a height of 50-70 m, with high wind power during summer [36]. The estimated annual mean wind power in the Red Sea was high (up to $500 \mathrm{~W} / \mathrm{m}^{2}$ ) in the central area due to Tokar gap winds, while it was moderate (100-300 W/ $\mathrm{m}^{2}$ ) along the coastal belt of Saudi Arabia, at a hub height of $80 \mathrm{~m}$ [37]. The western mountains of Saudi Arabia experience abundant wind resource potential compared to the Red Sea coastal areas [34]. In Kuwait, the peak wind power density is found along the coastal region during summer [35]. The calculated annual mean wind power in the Gulf was high in the central region, north of Qatar, of the order of $300 \mathrm{~W} / \mathrm{m}^{2}$ at a hub height of $50 \mathrm{~m}$ [38]. The winds in the Gulf are predominantly northwesterlies [39], with the highest wind speeds associated with shamal events, having a typical periodicity of 2-5 days [40]. The winter shamal winds are relatively stronger than the summer shamal winds [41]. The wind resource is more variable over the Gulf coast, compared to the Red Sea. Assessment of wind resource in the Gulf as a whole indicates that it is possible to produce a power of over $3000 \mathrm{GWh}$ per year [42]. 


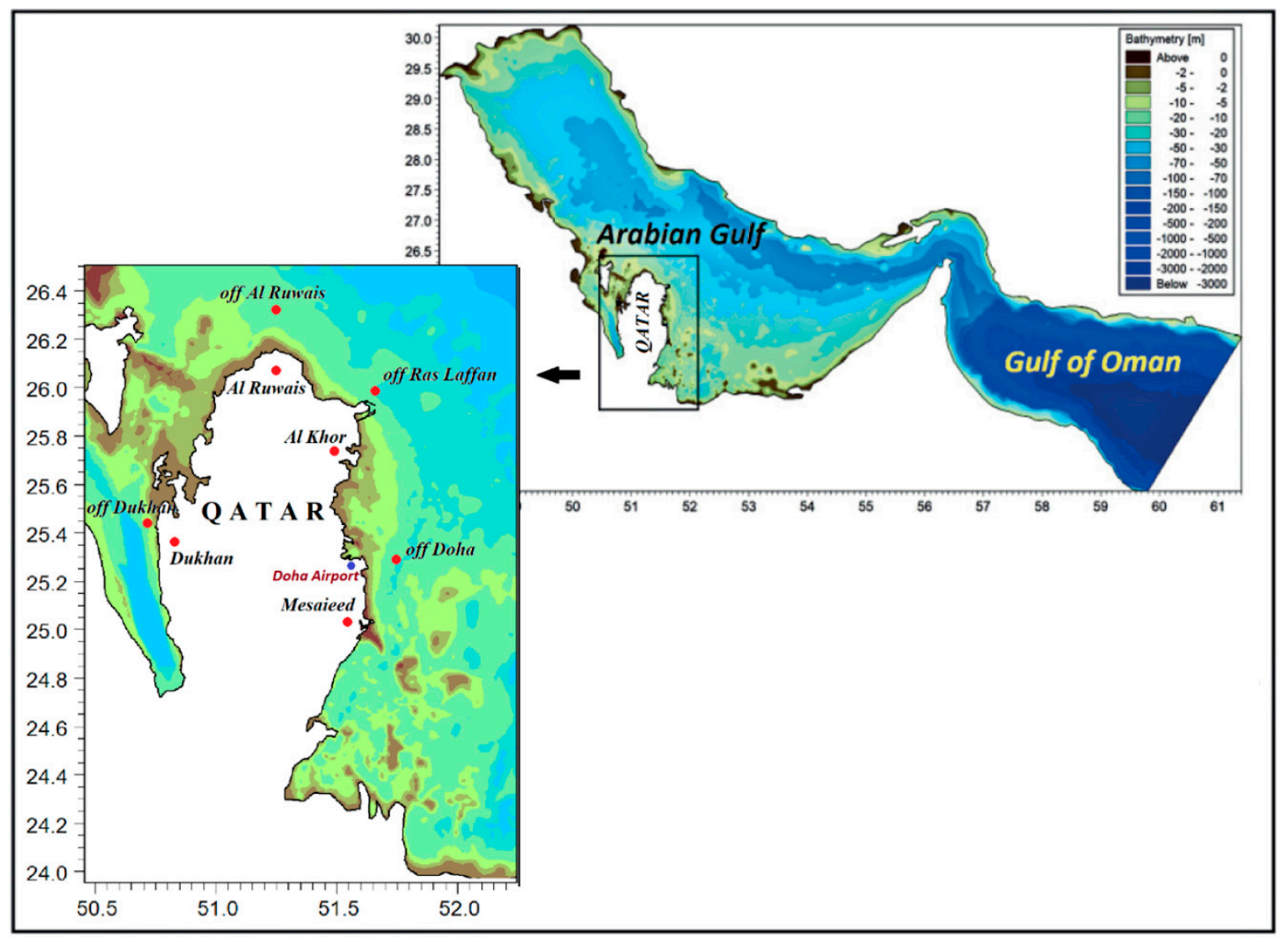

Figure 1. Study domain. Filled circles in red indicate the locations chosen for the wind resource assessment and those in blue indicate the wind measurement locations.

There are a few studies highlighting the wind energy resources and their feasibility in Qatar, and energy assessment has been carried out for a few locations based on the available measured data. The first attempt was made in 1990 based on the monthly averaged winds measured at Doha at a height of $10 \mathrm{~m}$ above ground level, and extrapolated to a height of $25 \mathrm{~m}$ [43]. Subsequent assessments were carried out using measured winds at Doha International Airport extrapolated to $20 \mathrm{~m}$ height, as well as at Halul Island [44]. These assessments covered only the central eastern coast of Qatar, and the data were limited to short-term measurements ( 25 years at the onshore location and just 1 year at the offshore location). The above onshore estimate at Doha is adequate for a useful assessment, but installation of a wind farm in a highly urbanized region is uncertain. Furthermore, the wind power estimated at Doha offshore needs to be reconsidered as that assessment was based on short-term measurements, and likely to be underestimated. Subsequently, a preliminary resource assessment study has been conducted recently in the context of a proposed wind farm near a natural gas processing plant on the northeast coast of Qatar based on two years of measurements (extrapolated to $130 \mathrm{~m}$ hub height) [45]. Although qualitatively agreeable, these assessments lack the treatment of uncertainties arising due to long-term variability as the duration of measured data is very short. Within these limitations, they identified that a plant can produce a wind power of $17 \mathrm{MW}$ in this region, and that would save 6.813 tons of $\mathrm{CO}_{2}$ and reduce the natural oil and gas consumption to a good extent.

The literature review shows the following gaps in the existing studies related to Qatar: (i) Earlier assessments were made only at a few locations based on short-term datasets, and hence, long-term datasets at a number of onshore and offshore locations are required to efficiently evaluate the wind resources, (ii) the spatial distribution of wind power within the exclusive economic zone (EEZ) of Qatar was not analyzed, and (iii) the effect of temporal variability and long-term trends in wind resource characterization were not treated, which 
is important to understand the role of climatic indices in the wind power variability and also to test the reliability of the wind power resource estimations. Hence, a proper assessment of wind power densities for Qatar, including onshore and offshore locations, will enable the identification of potential resource regions for efficiently executing the wind turbine generators (WTG) for power production. The rapid changes in the urbanization of Qatar and the associated sustainable developments demand implementation of such alternative energy productions. In this context, the present study was taken up with the aim to investigate the wind power resources of Qatar at eight select onshore and offshore locations using 40 years of re-analyzed ERA5 winds, and to resolve the existing gaps in the assessment.

The paper is organized as follows: The area of study and geographical features are detailed in Section 2; the data used and the methods adopted are given in Section 3; Section 4 describes the main results and the discussions, and it is divided into five subsections, describing wind climate, annual and decadal wind power, inter-annual variability in wind power, seasonal wind power, and monthly wind power; Section 5 summarizes the main interpretations.

\section{Area of Study}

Qatar is situated in the Gulf, between $24^{\circ} 00^{\prime} \mathrm{N}, 50^{\circ} 30^{\prime} \mathrm{E}$ and $26^{\circ} 00^{\prime} \mathrm{N}, 51^{\circ} 31^{\prime} \mathrm{E}$. It covers an area of $\sim 11,600 \mathrm{~km}^{2}$ (Figure 1). It is a relatively flat peninsula with natural topography that varies from 5 to $103 \mathrm{~m}$ above mean sea level (MSL). The north-to-south length of the Qatar peninsula is about $160 \mathrm{~km}$. The length of coastline is about $700 \mathrm{~km}$, extending from the Salwa Bay at the border of Saudi Arabia to the border of the United Arab Emirates. The exclusive economic zone (EEZ) of Qatar is approximately $35,000 \mathrm{~km}^{2}$ with an average water depth of $35 \mathrm{~m}$. The EEZ extends about $176 \mathrm{~km}$ seaward to the east and about $94 \mathrm{~km}$ to the north [46]. Qatar experiences an extreme humid and hot climate during summer and dry and cold climate during winter. It often experiences the shamal winds and dust storms. Significant warming has been identified in Qatar in recent decades [47]. In winter, shamal winds are dominant, which are considered as one among the extremes in the region [48]. In summer, the wind conditions are controlled by the prevailing regional and local climate systems. Summer shamal winds blow quite frequently, which brings dust from the northern parts of the Arabian Peninsula [23].

Four offshore and four onshore locations, representing the southeast, southwest, central east, north, and northeast regions of Qatar, were considered for site-specific resource assessment of wind energy extraction. The onshore locations are Mesaieed, Al Khor, and Dukhan. The offshore regions are off Doha, off Ras Laffan, off Al Ruwais, and off Dukhan. Doha, the capital city of Qatar, is situated on the central east coast, adjacent to the Doha Bay. The Mesaieed is an industrial area in the southeast part of Qatar, about $45 \mathrm{~km}$ south of Doha. Mesaieed Port located in the natural bay is the premier Port of Qatar, providing services to petrochemical industries, metallurgical plants, and construction-related industries. $\mathrm{Al}$ Khor is on the northeast coast, which is one of the major cities of Qatar, situated around $50 \mathrm{~km}$ north of Doha. Ras Laffan, located $80 \mathrm{~km}$ north of Doha, is an industrial city on the northeast coast of Qatar, developed and operated for the production of natural gas and its derivatives. Al Ruwais is on the northern tip of Qatar facing the central Gulf. It is about $127 \mathrm{~km}$ from Doha and holds Al Ruwais Port, which is the second-most important port in Qatar. Dukhan is on the west coast of Qatar, situated about $80 \mathrm{~km}$ west of Doha, known for its oil and natural gas reservoir.

\section{Data and Methods}

ERA5 is the updated reanalysis product of the European Centre for Medium-range Weather Forecasts (ECMWF), which provides hourly estimates of a large number of atmospheric, land, and oceanic climate variables (https:/ / www.ecmwf.int/en/forecasts / datasets/reanalysis-datasets/era5). It covers the Earth on a $30 \mathrm{~km}$ grid and resolves the atmosphere using 137 levels from the surface up to a height of $80 \mathrm{~km}$. It includes infor- 
mation about uncertainties for all variables at reduced spatial and temporal resolutions. In the ERA5 reanalysis winds, the scatterometer and in situ wind data are assimilated to improve the accuracy of predictions; thus, the long-term and short-term variabilities are reasonably well-captured [15]. The ERA5 winds are applied for wind climate studies [49], wind power assessments [21], and forcing the hydrodynamic and wave models [50]. In this study, we used the ERA5 surface winds of 40 years (1979-2018) for the assessment of wind power potential along the onshore and offshore locations of Qatar. This is a long-term dataset, useful for the evaluation of wind power resources as the long-term variability can be treated well. The ERA5 winds were validated with measurements in the Gulf, and a correlation coefficient of 0.95 and bias of 0.07 were obtained [51]. A few recent works utilized ERA5 winds for the wind climate and energy assessment studies [8,16,51].

The ERA5 winds have been compared with the measured winds (at $10 \mathrm{~m}$ height) at Doha Airport (Figure 1) obtained from the Qatar Meteorology Department (QMD) website, which are available for every $1 \mathrm{~h}$ on a daily basis. We used the data during Dec 2019 to April 2020 for validation (Figure 2). The wind speeds are given in integers such as 5 knots, 6 knots, etc., which has been converted to $\mathrm{m} / \mathrm{s}$. The wind direction is given with $22.5^{\circ}$ spacing (like NNE, NE, ENE, etc.). Within the limitations of available measured data, ERA5 winds give a reasonable match with the measured winds. The correlation coefficient between the measured and ERA5 wind speeds is 0.78 , bias $1.30 \mathrm{~m} / \mathrm{s}$, and RMSE $2.22 \mathrm{~m} / \mathrm{s}$ $(17.2 \%$ with the maximum wind speed). There is a relatively wider scatter between the measured and ERA5 wind speeds and directions, which are due to numerical limitations in the measured data availability (in the website) and also coarser spatial resolution $\left(0.25^{\circ} \times\right.$ $0.25^{\circ}$ ) of the ERA5 data. Moreover, the measurement location is at the land-sea boundary and the data are subject to terrain effects, whereas the ERA5 data mostly represent the sea conditions.

Wind power assessments are commonly carried out at various hub heights $(50,70,90$, $120 \mathrm{~m}$, etc.) and most of the wind resource characterizations are based on winds that are reconstructed from the $10 \mathrm{~m}$ height, assuming neutral stability conditions (e.g., [8,34,37]). In the present study, we applied a hub height of $90 \mathrm{~m}$ as a reference for the wind power assessment, targeting the 2.1 MW WTG such as Suzlon S97 (https: / /www.suzlon.com/in-en/ energy-solutions/). Hence, the wind speeds at $10 \mathrm{~m}$ height $\left(\mathrm{U}_{10}\right)$ have been reconstructed to $90 \mathrm{~m}$ height $\left(\mathrm{U}_{90}\right)$ using a logarithmic wind profile [52].

$$
U(z)=\frac{U_{*}}{\kappa} \ln \frac{Z}{Z_{0}}
$$

where $U(z)$ is the wind speed at a height $(Z=90 \mathrm{~m}), U_{*}$ is the surface friction velocity derived from $U_{10}, Z_{0}$ is the aerodynamic roughness length (=0.005 assuming a smooth surface), and $\kappa=0.4$ is the von Karman constant. The selected onshore regions are basically flat terrains with a negligible amount of vegetation or obstruction. Hence, we used a similar roughness length for both offshore and onshore areas.

The wind power generation capacity is generally determined by the annual mean wind speeds derived from time series data or by their probability distributions. In a few studies, the wind power potential was estimated using the probability distributions such as Weibull, Rayleigh, and log-normal distributions [53-56]. These distributions have also proved effective in the wind power generation. The typical cut-in wind speed for the generation of wind power in a small turbine is $3.5 \mathrm{~m} / \mathrm{s}$, and at least $2 \mathrm{~m} / \mathrm{s}$ wind speed is required to start rotating the turbines. The wind power generators are generally designed for maximum wind speeds, of the order of 10-15 m/s [57]. The cut-out speed for most of the turbines is $25 \mathrm{~m} / \mathrm{s}$ [58]. Recently, slow-wind-speed wind turbines have also been designed [59-61], and their efficiency in low wind speeds $(\sim 3 \mathrm{~m} / \mathrm{s})$ is better than those designed for moderate or strong winds. Effective operation of wind turbines and the forecast of wind power outputs can be achieved using ARIMA-GARCH(-M) approachbased models, which can predict both the mean and volatility of wind speed [62]. 
(a)

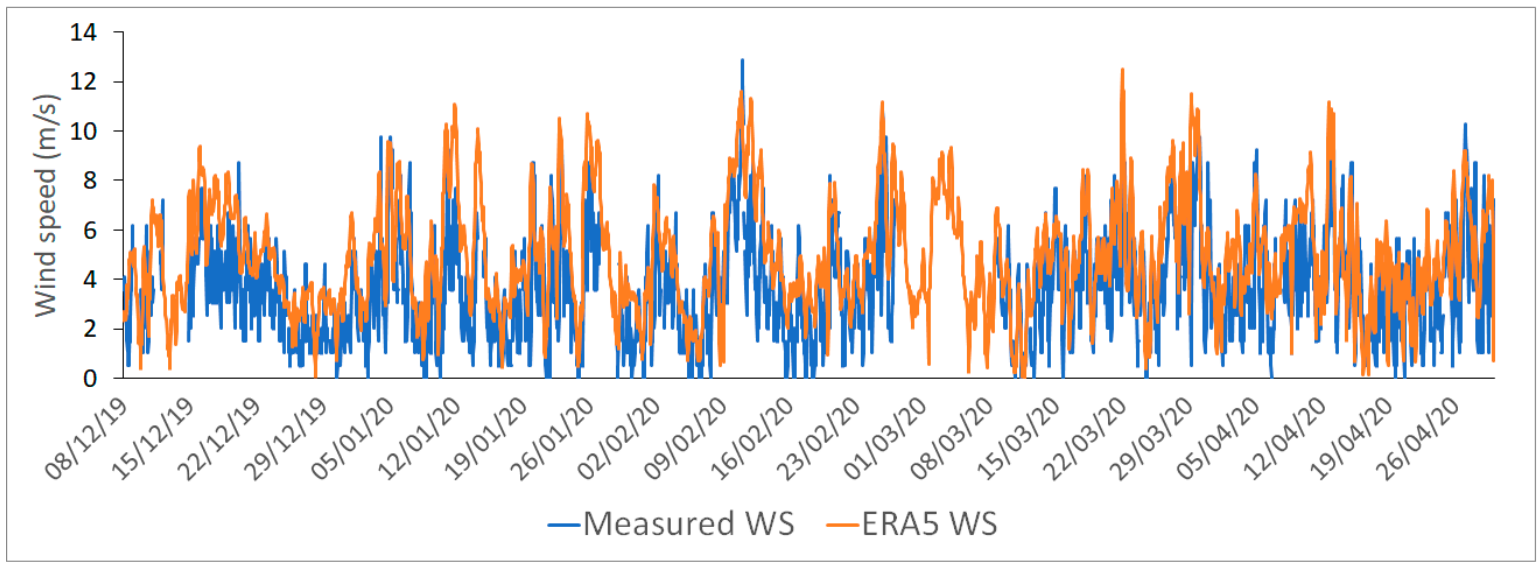

(b)

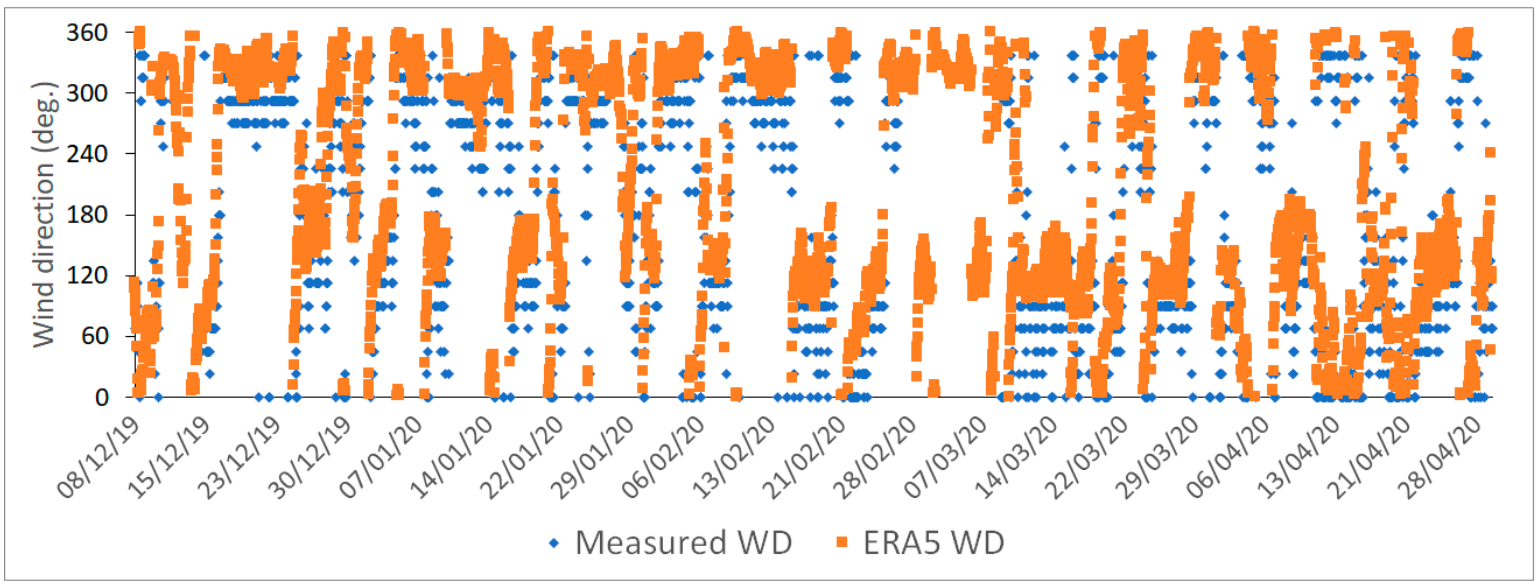

Figure 2. Comparison between measured and ECMWF Reanalysis v5 (ERA5) winds during 8 December 2019-30 April 2020: (a) wind speed and (b) wind direction.

The wind power density is the number of watts of electrical energy produced per square meter of air space $\left(\mathrm{W} / \mathrm{m}^{2}\right)$, computed using the following equation:

$$
P_{A}=\frac{1}{2} \rho V^{3}
$$

where $\rho$ is the air density and $V$ is the wind speed. The air density could be variable, depending on the variations in temperature and pressure in different time spans (diurnal to seasonal). This may have certain impacts on the wind power estimations [63]. Moreover, accurate representation of air density variation is often difficult to obtain due to insufficient data, especially when a longer historical period is taken into account. Thus, we used $\rho=$ $1.225 \mathrm{~kg} / \mathrm{m}^{3}$, the standard air density in the estimations of wind power. The wind power density is an independent estimation, irrespective of the turbine features. For actual power production, the mechanics of the flow passing through the blades and the efficiency of the generator must be taken into account [36].

In the present study, the time series of wind power densities of Qatar has been calculated using 40 years (1979-2018) of hourly wind data extracted from ERA5. This has been processed to derive the statistics of the wind power densities for each month, season, year, decade, and the 40 year period. The spatial distributions of annual, decadal, inter-annual, seasonal, and monthly mean and standard deviations have been computed. These have been analyzed for site-specific locations. The trends have been evaluated using the Sen's slope estimate $[64,65]$. 
The resource variability and effectiveness have been analyzed by estimating the standard deviation (SD), coefficient of variation (CoV), skewness (Sk), kurtosis (K), and variability indices such as annual variability index (AVI), seasonal variability index (SVI), and monthly variability index (MVI). The SD is expressed as:

$$
\sigma=\sqrt{\frac{\left(x_{i}-\mu\right)^{2}}{N}}
$$

where $x_{i}$ is the value of the variable in each time step, $\mu$ is the mean of the variable, and $\mathrm{N}$ is the total number of timestep.

$\mathrm{CoV}$ is used to evaluate the dispersion of wind power distributions around their mean values [66]. It is the ratio of the SD to the mean.

The $S k$ and $K$ are expressed as:

$$
\begin{gathered}
S k=\frac{N^{-1} \sum_{i=1}^{N}\left(x_{i}-\mu\right)^{3}}{\sigma^{3}} \\
K=\frac{N^{-1} \sum_{i=1}^{N}\left(x_{i}-\mu\right)^{4}}{\sigma^{4}}
\end{gathered}
$$

The AVI/SVI/MVI is the difference of mean values between the most energetic and least energetic years/seasons/months divided by the annual mean for the years in consideration [67].

$$
\begin{aligned}
A V I & =\frac{P_{Y \text { max }}-P_{Y \text { min }}}{P_{Y}} \\
S V I & =\frac{P_{S \text { max }}-P_{S \text { min }}}{P_{Y}} \\
M V I & =\frac{P_{M \text { max }}-P_{M \text { min }}}{P_{Y}}
\end{aligned}
$$

where $P_{Y \text { max }}$ is the maximum annual mean power densities, $P_{Y}$ min is the minimum annual mean power densities, $P_{S \max }$ is the maximum seasonal mean power densities, $P_{S}$ min is the minimum seasonal mean power densities, $P_{M \text { max }}$ is the maximum monthly mean power densities, $P_{M \text { min }}$ is the minimum monthly mean power densities, and $P_{Y}$ is the mean power density considering the entire duration.

\section{Results and Discussion}

\subsection{Wind Climate}

The wind climate at $90 \mathrm{~m}$ height during the 40 year period (1979-2018) has been analyzed. The $90 \mathrm{~m}$ height chosen for the wind climate analysis is to align it with the height chosen for the wind power estimations. The wind rose indicates that the dominant winds around Qatar are from the WNW-NNE directional sector (Figure 3). Around 55\% (Mesaieed onshore) to $66 \%$ (offshore Ruwais) of winds are from the above directional sector. Winds due to land/sea breezes and other local wind systems are also present in reasonable quantities in other directions. The wind patterns are similar along the east and north coasts, but marginally different along the west coast (e.g., at Dukhan) with a deviation of $\approx 20^{\circ}$ in the dominant patterns by the influence of regional orography such as the presence of Bahrain Island and an extended bay along the southwest corner of Qatar (the Salwa Bay). The offshore wind speeds are generally higher than the onshore wind speeds. The wind speeds are higher in the northern regions such as Ruwais offshore, which has a high exposure to shamal winds, being part of the central Gulf. Around $2-4 \%$ of winds in the onshore regions and $3-7 \%$ of winds in the offshore regions have magnitudes greater than $10 \mathrm{~m} / \mathrm{s}$. 
(a) Onshore
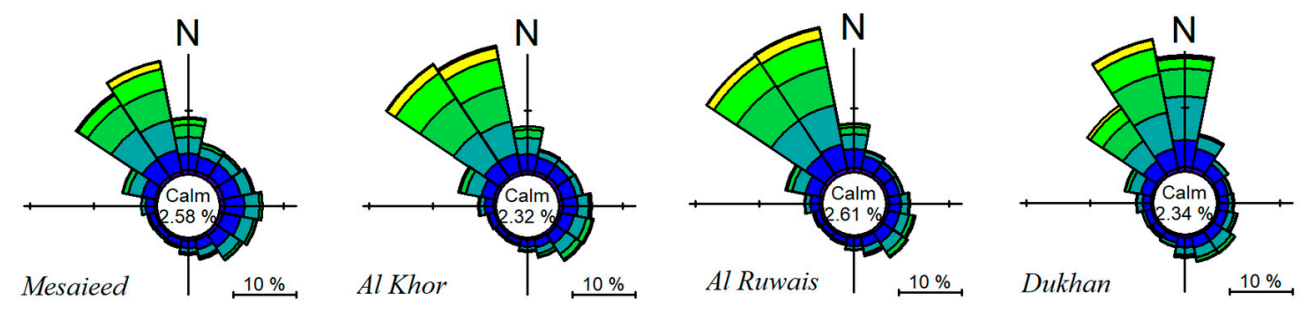

(b) Offshore
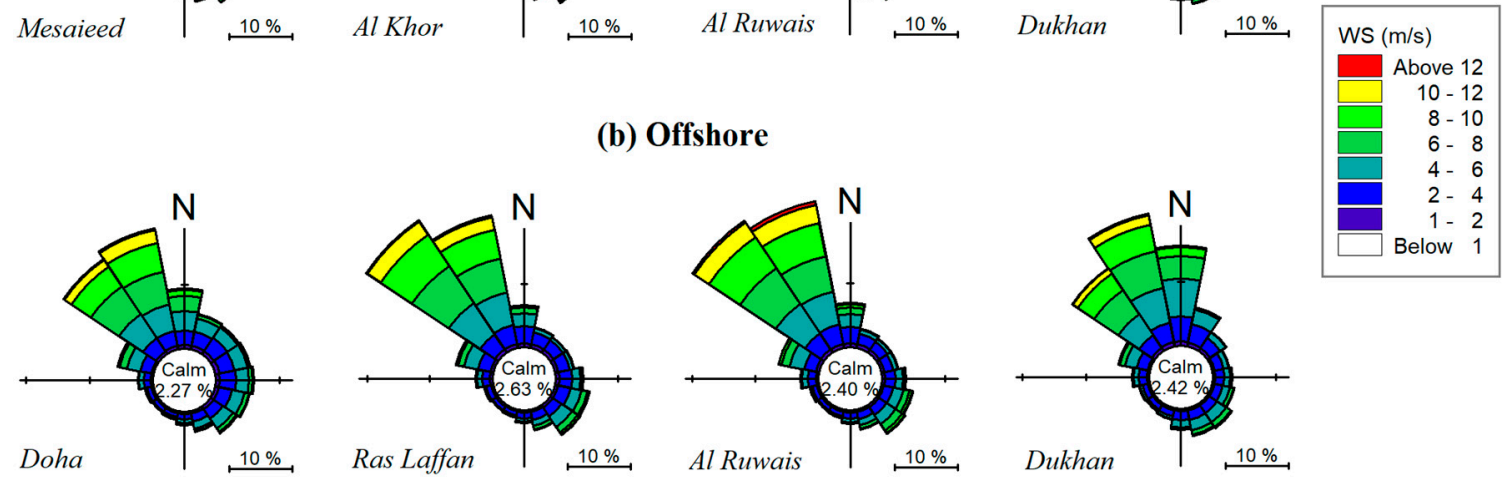

Figure 3. Wind rose at $90 \mathrm{~m}$ height during 1979-2018 at select (a) onshore and (b) offshore locations.

The onshore wind speeds at Mesaieed are relatively small (mean and maximum wind speeds are 4.6 and $15.4 \mathrm{~m} / \mathrm{s}$, respectively) compared to other locations (Table 1 ). The highest wind speeds are found at Ruwais offshore, where mean and maximum wind speeds are 5.5 and $16.9 \mathrm{~m} / \mathrm{s}$, respectively. The range of mean wind speeds obtained in the onshore and offshore regions of Qatar $(4.6-5.5 \mathrm{~m} / \mathrm{s})$ is adequate to operate wind power turbines for successful electricity production $[44,45]$. The majority of wind farms around the globe operate the plants with annual mean wind speeds in the range of 5-8 m/s [68]. For example, the wind farms of Italy and the Adriatic Sea are characterized by the exploitable mean wind speeds of 5-6 m/s [69]. However, the exploitable wind speeds are generally between 3 and $25 \mathrm{~m} / \mathrm{s}$ based on the wind turbine designs established worldwide [70]. Based on this criterion, we find that the occurrences of exploitable wind speeds at the onshore and offshore locations of Qatar are 74-78\% and 77-79\%, respectively (Table 1). This is a good estimate and consistent with the occurrences of exploitable wind speeds in the Red Sea [37].

Table 1. Wind speed statistics at onshore and offshore locations during 1979-2018.

\begin{tabular}{|c|c|c|c|c|c|c|c|}
\hline \multirow{2}{*}{ Region } & \multirow{2}{*}{ Locations } & \multicolumn{2}{|c|}{$\begin{array}{l}\text { Geographical } \\
\text { Co-Ordinates }\end{array}$} & \multicolumn{3}{|c|}{ Wind Speed (m/s) } & \multirow{2}{*}{$\begin{array}{c}\% \text { of } \\
\text { Exploitable } \\
\text { Wind } \\
\text { Speed }\end{array}$} \\
\hline & & $\begin{array}{c}\text { Longitude } \\
\left({ }^{\circ} \mathrm{E}\right)\end{array}$ & $\begin{array}{c}\text { Latitude } \\
\left({ }^{\circ} \mathrm{N}\right)\end{array}$ & Maximum & Mean & $\begin{array}{l}\text { Standard } \\
\text { Deviation }\end{array}$ & \\
\hline \multirow{4}{*}{ Onshore } & Mesaieed & 51.5828 & 25.0444 & 15.4 & 4.6 & 2.3 & 73.9 \\
\hline & Al Khor & 51.4394 & 25.7534 & 16.2 & 5.1 & 2.6 & 77.1 \\
\hline & Al Ruwais & 51.2202 & 26.0690 & 15.9 & 4.9 & 2.5 & 74.7 \\
\hline & Dukhan & 50.8398 & 25.3355 & 15.7 & 4.9 & 2.4 & 77.5 \\
\hline \multirow{4}{*}{ Offshore } & Doha & 51.7970 & 25.2755 & 15.5 & 5.1 & 2.5 & 78.5 \\
\hline & Ras Laffan & 51.6146 & 26.0131 & 16.5 & 5.2 & 2.7 & 76.5 \\
\hline & Al Ruwais & 51.2992 & 26.2822 & 16.9 & 5.5 & 2.8 & 78.4 \\
\hline & Dukhan & 50.7251 & 25.4767 & 16.1 & 5.0 & 2.4 & 78.2 \\
\hline
\end{tabular}

The monthly mean wind speeds at the onshore locations are smaller than those at the offshore locations; however, the pattern of variation is nearly the same (Figure 4) because of no major uneven terrain features and the proximity to the locations. The wind speeds during February and June are highly influenced by the winter shamal and summer shamal 
winds, respectively, and this is evident from the peaks observed. This is consistent with earlier observations in the central Gulf [26]. In the onshore regions of east and north coasts of Qatar, the highest monthly mean wind speed is estimated during June, whereas in the onshore region of the west coast (Dukhan), the highest monthly mean wind speed is estimated during February. However, the differences in magnitudes during February, as well as June, at all the onshore locations are marginal. Similar features have been observed at the offshore locations, except at $\mathrm{Al}$ Ruwais. This indicates that winter and summer shamals during February and June, respectively, equally dominate most parts of Qatar, except offshore regions of the north, where the winter shamal exhibits a clear dominance over the summer shamal. This substantiates the view of earlier studies $[24,26,51]$ that the winter shamal winds affect the central regions of the Gulf compared to other parts, while the summer shamal winds significantly affect the northwest regions including the desert areas. The monthly mean patterns of wind speeds onshore and offshore of Qatar are consistent with those derived within the EEZ or adjacent regions in the Gulf using ERAInterim winds [26]. However, it differs marginally in magnitude due to (i) the difference in the hub height in consideration and (ii) the under-estimation of ERA-Interim winds compared to ERA5 winds because of the coarser temporal and spatial resolutions.

(a) Onshore

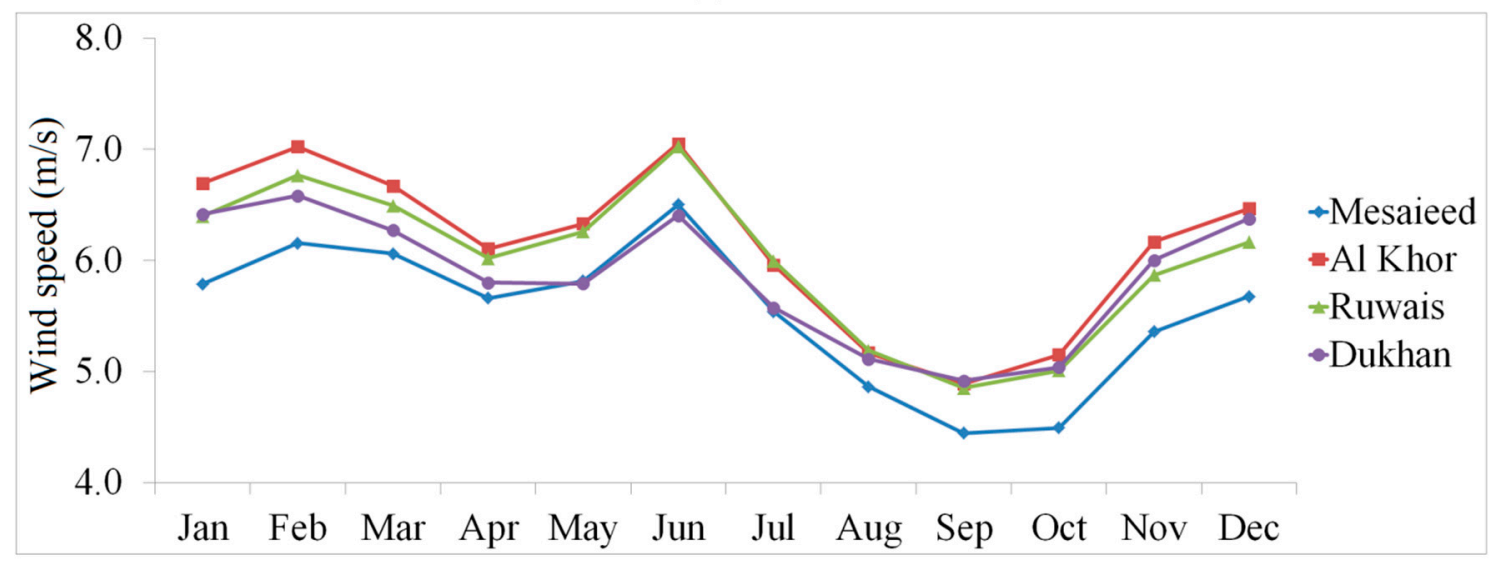

(b) Offshore

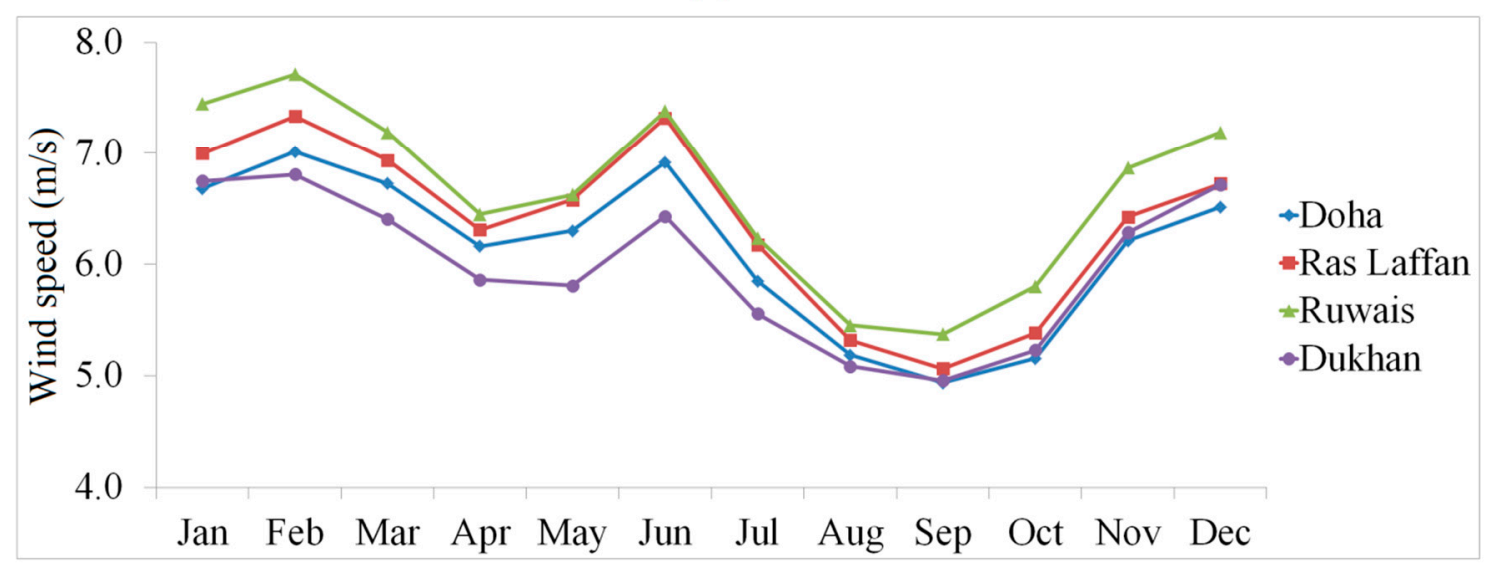

Figure 4. Monthly mean wind speeds at (a) onshore and (b) offshore locations of Qatar at a height of 90 m during 1979-2018.

\subsection{The Annual and Decadal Wind Power}

The 40 year mean wind power density estimated at $90 \mathrm{~m}$ height indicates that the mean power density is maximum in the north and northeast regions off Qatar, reaching up to $250 \mathrm{~W} / \mathrm{m}^{2}$ (Figure $5 \mathrm{a}$ ). The SD is higher than the mean (up to $330 \mathrm{~W} / \mathrm{m}^{2}$ ), indicating a 
higher variability in wind power during the 40 year period (Figure $5 b$ ). The mean wind power densities in the offshore regions are relatively higher than those in the onshore regions (Figure 5c). These are consistent with the mean wind power estimated along the coastal regions of a few marginal seas and along the Indian coasts [16,71].

(a) Mean

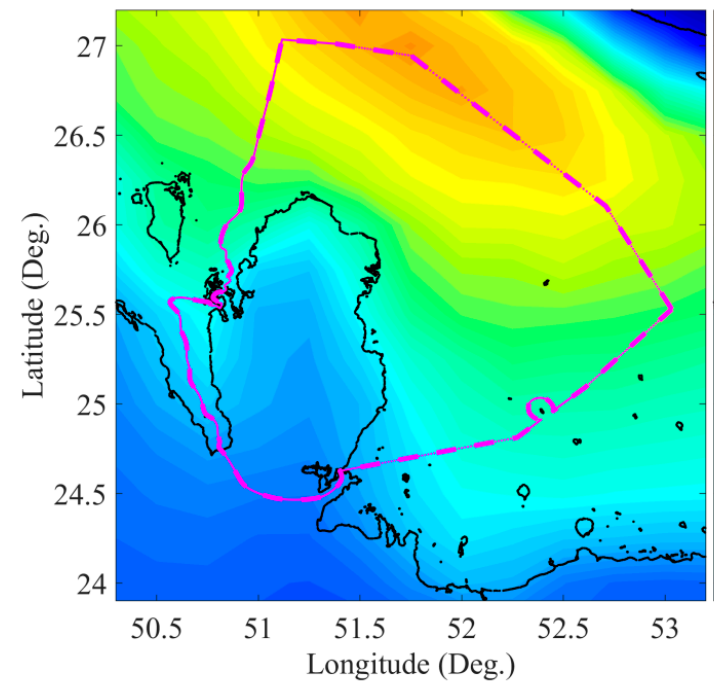

(b) Standard deviation

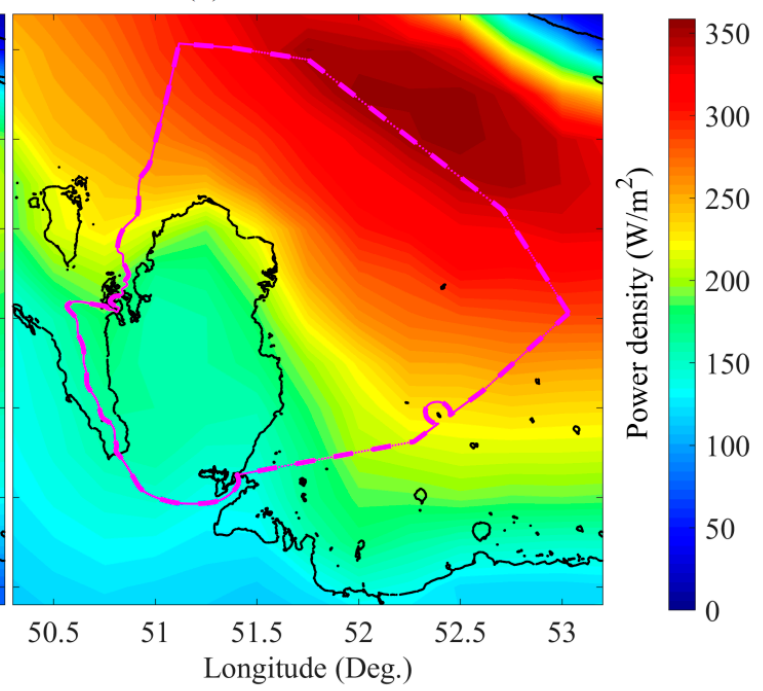

(c)

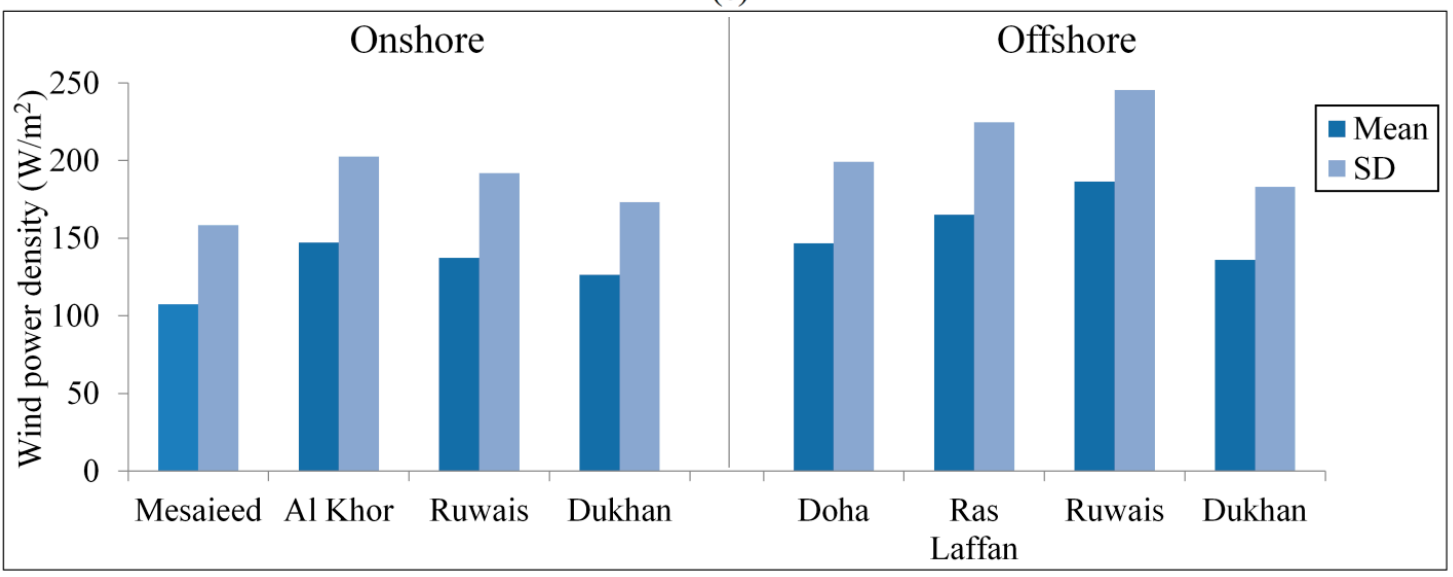

Figure 5. The mean and standard deviation of wind power density for the period 1979-2018: (a) Mean wind power density (spatial), (b) standard deviation (spatial), (c) mean wind power density, and standard deviations at select onshore and offshore locations. The pink dashed lines indicate the exclusive economic zone (EEZ) of Qatar.

More specifically, the mean wind power densities in the offshore regions of $\mathrm{Al}$ Ruwais, Ras Laffan, Doha, and Dukhan are 186, 165, 147, and $136 \mathrm{~W} / \mathrm{m}^{2}$, respectively (Table 2). The mean wind power densities in the onshore regions of Al Khor, Al Ruwais, Dukhan, and Mesaieed are $147,137,127$, and $107 \mathrm{~W} / \mathrm{m}^{2}$, respectively. There is a large difference in wind power between the onshore and offshore locations of Al Ruwais, while the difference is small between the onshore and offshore locations of $\mathrm{Al} \mathrm{Khor.} \mathrm{This} \mathrm{is} \mathrm{because} \mathrm{the} \mathrm{northern}$ offshore region of Qatar EEZ is relatively wider and experiences higher wind speeds (especially during shamal events).

The maximum hourly wind power densities estimated from the time-series (not shown) during the 40 year period at the offshore locations are as follows: Al Ruwais, $2960 \mathrm{~W} / \mathrm{m}^{2}$ (13 January 1998); Ras Laffan, $2784 \mathrm{~W} / \mathrm{m}^{2}$ (3 February 2017); Dukhan, $2548 \mathrm{~W} / \mathrm{m}^{2}$ (13 January 1998); and Doha, $2273 \mathrm{~W} / \mathrm{m}^{2}$ (3 February 2017). The maximum hourly wind power densities estimated at the onshore locations are as follows: Al Khor, $2604 \mathrm{~W} / \mathrm{m}^{2}$ (3 February 2017); $\mathrm{Al}$ Ruwais, 2467 W/m² (3 February 2017); Dukhan, 2379 W/m² (18 March 1998); and Mesaieed, 
$2250 \mathrm{~W} / \mathrm{m}^{2}$ (1 April 2015). If we refer to the dates given in the brackets, it is evident that the wind power of these magnitudes has been achieved due to the northwesterly extreme shamal winds occurring in the Gulf during winter. The date of occurrence of maximum values is different at these locations because of the spatial variability within the boundaries of Qatar, although the area bounded is relatively small.

Table 2. Statistics of wind power density at onshore and offshore locations of Qatar for the period 1979-2018.

\begin{tabular}{|c|c|c|c|c|c|c|c|}
\hline \multirow{2}{*}{ Region } & \multicolumn{7}{|c|}{ Statistics of Wind Power Density } \\
\hline & Locations & Mean $\left(W / m^{2}\right)$ & $\begin{array}{c}\operatorname{Max} \\
\left(\mathrm{W} / \mathrm{m}^{2}\right)\end{array}$ & $\mathrm{SD}\left(\mathrm{W} / \mathrm{m}^{2}\right)$ & CoV & Sk & $\mathbf{K}$ \\
\hline \multirow{4}{*}{ Onshore } & Mesaieed & 107.4 & 2249.6 & 158.5 & 1.48 & 3.18 & 17.30 \\
\hline & Al Khor & 147.3 & 2604.2 & 202.6 & 1.38 & 2.52 & 11.43 \\
\hline & Al Ruwais & 137.3 & 2467.1 & 192.0 & 1.40 & 2.57 & 11.93 \\
\hline & Dukhan & 126.5 & 2378.5 & 173.3 & 1.37 & 2.75 & 13.48 \\
\hline \multirow{4}{*}{ Offshore } & Doha & 146.7 & 2273.1 & 199.2 & 1.36 & 2.55 & 11.62 \\
\hline & Ras Laffan & 165.3 & 2783.8 & 224.7 & 1.36 & 2.32 & 9.84 \\
\hline & Al Ruwais & 186.4 & 2960.3 & 245.4 & 1.32 & 2.22 & 9.42 \\
\hline & Dukhan & 136.1 & 2547.7 & 183.1 & 1.35 & 2.61 & 12.31 \\
\hline
\end{tabular}

The SD of wind power is higher than the mean values in all the locations. This indicates that the relative variation (with respect to mean values) of wind power is higher. Such variations are expected in a long-term data set. The maximum and minimum values of SDs are 245 and $159 \mathrm{~W} / \mathrm{m}^{2}$ at offshore Ruwais and onshore Mesaieed, respectively. The $\mathrm{CoV}$ is relatively higher at the onshore regions (1.37-1.48) than at the offshore regions (1.32-1.36) of Qatar. These values are generally small, which are consistent with the CoV derived along the Romanian coast, Sea of Azov, and across Europe [66,71]. The low CoV indicates a stable environment, favorable for wind power extraction. It means that the impact of wind variability on the electric power grid is low, and thus, the cost involved in power generation and distribution can be optimized [72].

Sk and $\mathrm{K}$ represent the higher moments of wind power, and they are useful to evaluate the existence and frequency of extremes. Higher values of Sk and $\mathrm{K}$ indicate the prevalence of unstable behavior. The Sk values at the onshore regions of Qatar vary from 2.5 to 3.2, while those at the offshore regions vary from 2.2 to 2.6. Similarly, K values at the onshore regions vary from 11.4 to 17.3 , while those at the offshore regions vary from 9.4 to 12.3 . In general, the $\mathrm{Sk}$ and $\mathrm{K}$ values are small, and this indicates that the occurrence of extremes is very rare and the magnitude of the strong wind events is relatively small. The accuracy of the statistical values is proved by the fact that no extreme events (in this case, tropical cyclones) have been recorded, not even in the 40 year period in consideration; the first known storm that entered the Gulf was during October 1948 [73].

The decadal mean wind power densities show that there is no significant variation in mean wind power among the four decades (Figure 6). This indicates that available decadal wind power is nearly consistent throughout the period, although smaller temporal scale variations such as seasonal and inter-annual variabilities may exist in this region. The maximum decadal mean wind power density onshore is at Al Khor $\left(146-151 \mathrm{~W} / \mathrm{m}^{2}\right)$, whereas that offshore is at Al Ruwais $\left(180-191 \mathrm{~W} / \mathrm{m}^{2}\right)$. The onshore Mesaieed receives the lowest wind energy potential among the selected locations. 


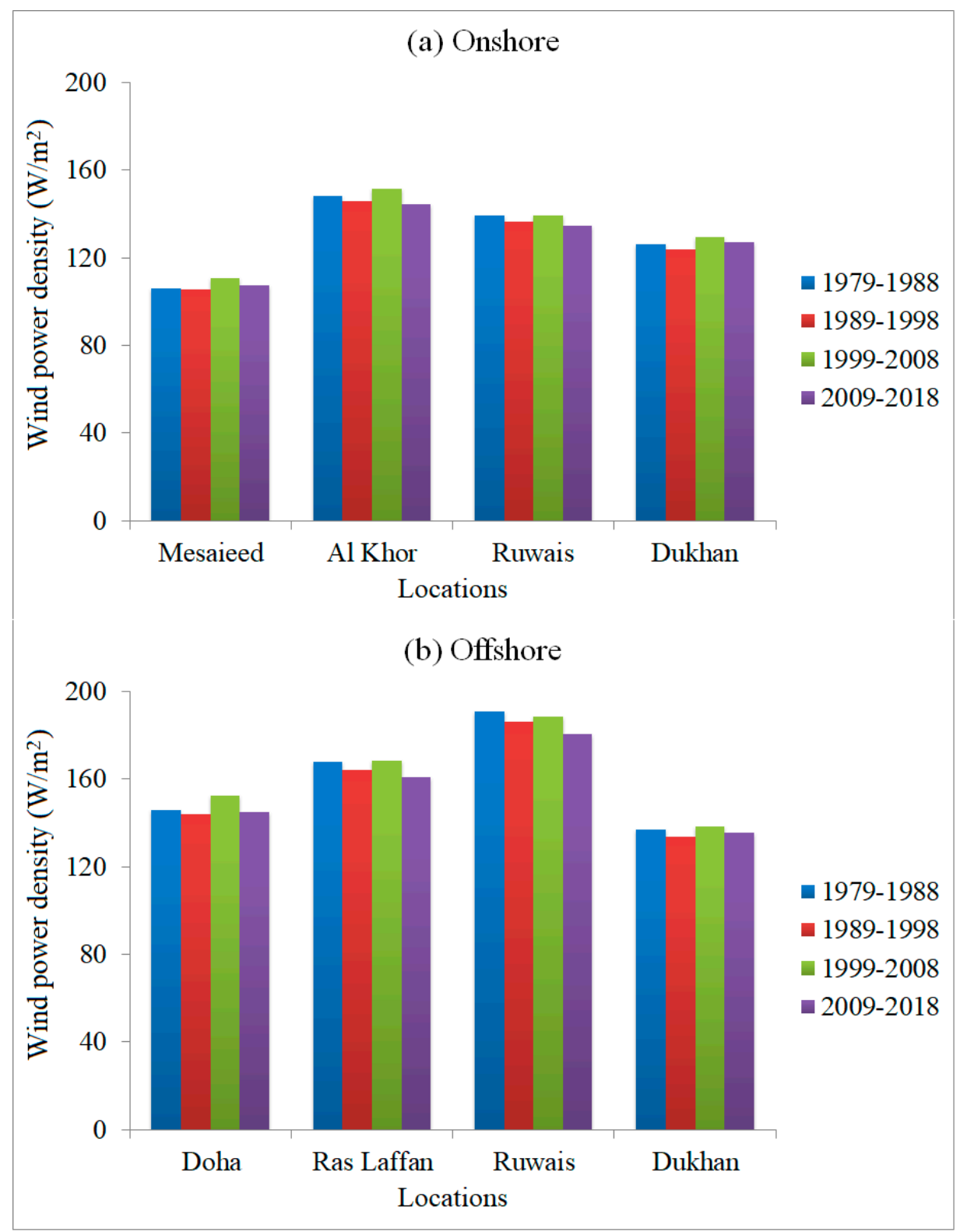

Figure 6. Decadal mean wind power density during 1979-2018 at select (a) onshore and (b) offshore locations.

\subsection{Inter-Annual Variability and Trends}

The annual mean wind power densities at onshore and offshore locations for each year have been estimated (Figure 7). The maximum annual mean wind power is found to be in 2011, while the minimum is during 2010. The years 2010 and 2011 are considered the years of largest variations in wind power. Inter-annual variability is evident throughout the study period, which is primarily contributed by the climate indices, especially the El Niño Southern Oscillation (ENSO). The annual variation in wind power at onshore and offshore locations of Qatar has an inverse relationship with the Multivariate ENSO Index (MEI). MEI is a method used to characterize the intensity of ENSO events through historical analysis. It combines both oceanic and atmospheric variables and facilitates a single index assessment of ENSO. A higher positive MEI indicates a warm phase of ENSO (El Niño) and a lower negative MEI indicates a cool phase of ENSO (La Niña). The estimated wind power at the onshore and offshore locations of Qatar has reduced during the strongest El Niño events (e.g., 1982-1983, 1997-1998, and 2015-2016), and increased during the strongest La Niña events (e.g., 1988-1989, 1999-2000, and 2010-2011). This is consistent with the 
modulation of wind speeds with ENSO and Indian Ocean Dipole (IOD) identified during winter along the inland areas of the United Arab Emirates, an adjacent region of Qatar [74]. Similar variabilities have been observed in the Red Sea as well [75]. In addition, the shamal winds in the Middle East have shown significant modifications, i.e., an early onset and termination, during La Niña events [23].

(a) Annual mean wind power at onshore

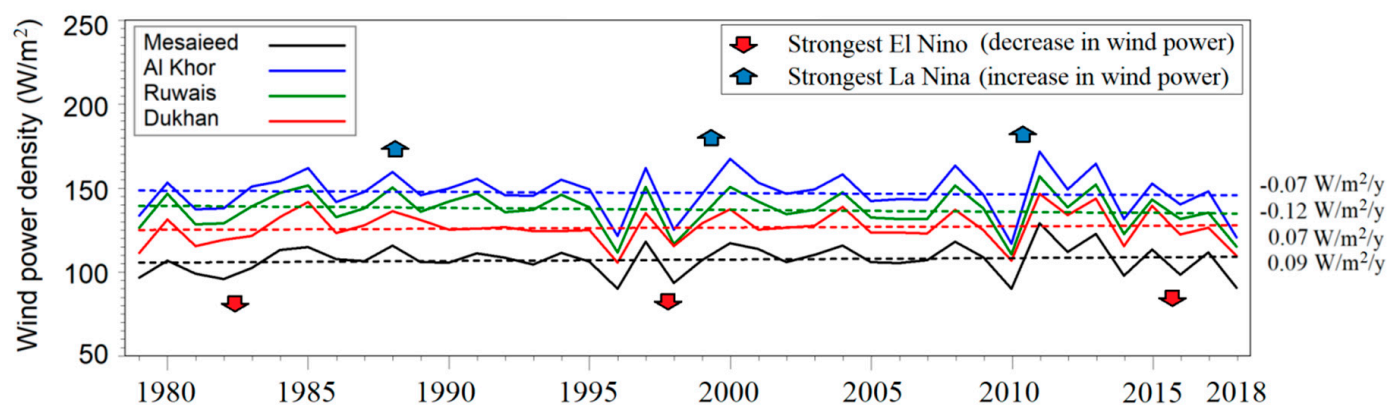

(b) Annual mean wind power at offshore

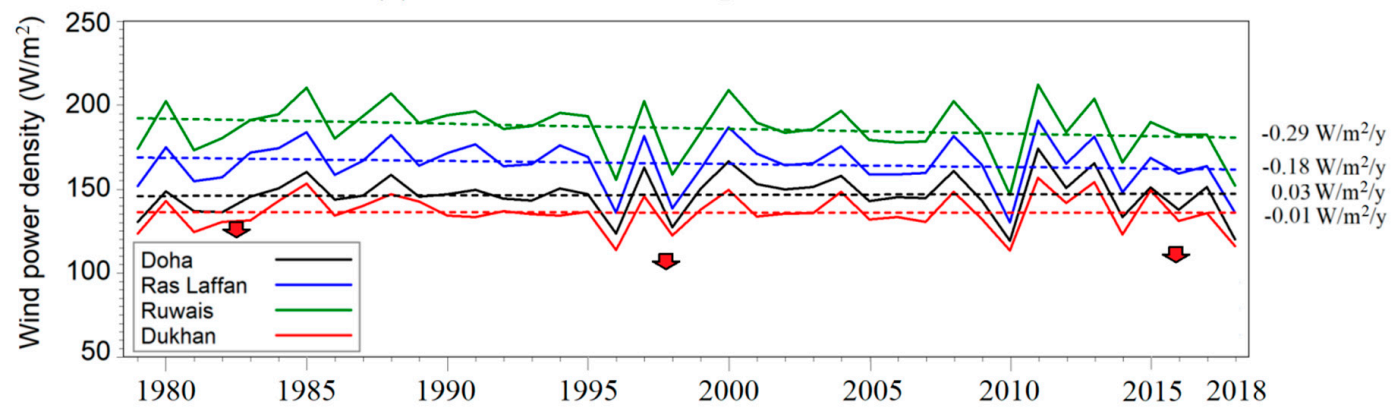

(c) Multivariate ENSO Index

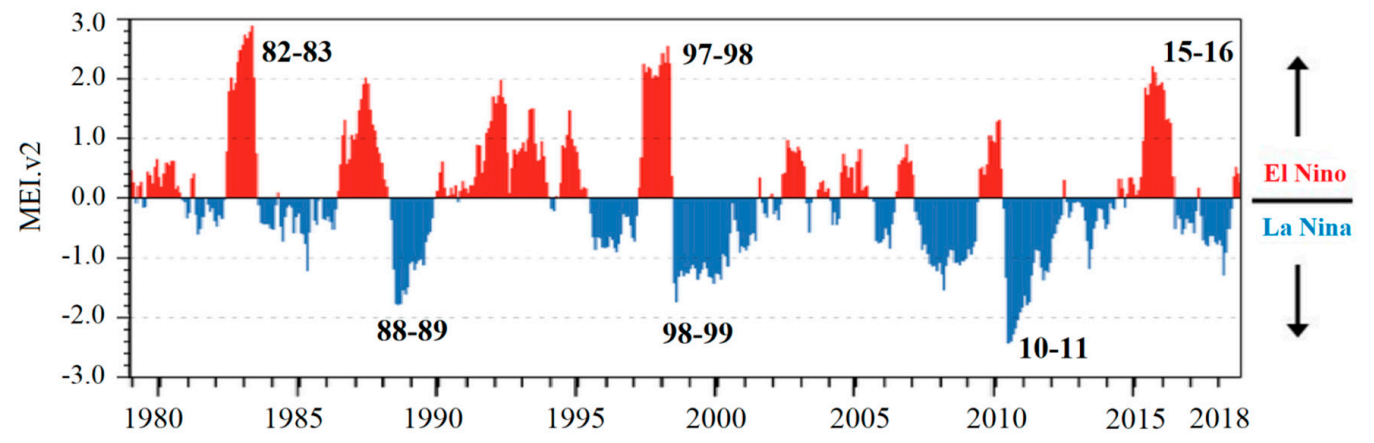

Figure 7. Annual mean wind power density during 1979-2018 at select (a) onshore and (b) offshore locations and (c) the multivariate El Niño-Southern Oscillation (ENSO) Index.

The highest and lowest annual mean wind power densities and their variations at the onshore and offshore locations of Qatar are given in Table 3. Offshore of Al Ruwais, the highest annual mean wind power is exhibited, while onshore of Mesaieed, the lowest annual mean wind power is shown. The percentage of variations (with respect to the lowest annual mean) is in the range of $38-47 \%$ along these locations with the maximum variation in onshore $\mathrm{Al}$ Khor and offshore Ras Laffan and the minimum in onshore Dukhan.

Despite the strong inter-annual variability, the trend estimations of wind power densities give weak positive and negative trends at the onshore and offshore locations of Qatar (Figure 7 and Table 4). The increment in annual mean wind power density at the onshore locations is within $-0.08-0.08 \%$, while that at the offshore locations is within 
$-0.15 \%-0.02 \%$. The decreasing trends are in the north and northeast regions of Qatar, while the remaining areas of Qatar show increasing trends.

Table 3. The variations in annual mean wind power during 1979-2018 at select onshore and offshore locations.

\begin{tabular}{cccccc}
\hline \multirow{2}{*}{ Region } & \multirow{2}{*}{ Locations } & \multicolumn{2}{c}{ Annual Mean Wind Power $\left(\mathbf{W} / \mathbf{m}^{\mathbf{2}}\right)$ during $\mathbf{1 9 7 9 - 2 0 1 8}$} & \multirow{2}{*}{ \% of Variation } \\
\cline { 3 - 5 } & & Highest & Lowest & Highest-Lowest & \\
\hline \multirow{3}{*}{ Onshore } & Mesaieed & 129.1 & 90.0 & 39.1 & 43.4 \\
& Al Khor & 171.8 & 117.0 & 54.8 & 46.8 \\
& Al Ruwais & 157.0 & 110.7 & 46.3 & 41.8 \\
& Dukhan & 146.6 & 105.6 & 41.0 & 38.8 \\
\hline \multirow{5}{*}{ Offshore } & Doha & 174.0 & 119.2 & 54.8 & 46.0 \\
& Ras Laffan & 190.7 & 130.1 & 60.6 & 46.6 \\
& Al Ruwais & 212.2 & 146.8 & 65.4 & 44.6 \\
& Dukhan & 156.9 & 113.4 & 43.5 & 38.4 \\
\hline
\end{tabular}

Table 4. The variations in mean wind power during 1979-2018 at onshore and offshore locations.

\begin{tabular}{|c|c|c|c|c|c|}
\hline \multirow{2}{*}{ Region } & \multirow{2}{*}{ Locations } & \multirow{2}{*}{$\begin{array}{l}\text { Mean Wind Power } \\
\text { during } 1979\end{array}$} & \multicolumn{2}{|c|}{ Increment in Mean Wind Power $\left(\mathrm{W} / \mathrm{m}^{2}\right)$} & \multirow{2}{*}{$\begin{array}{l}\text { Annual } \% \text { of } \\
\text { Increment }\end{array}$} \\
\hline & & & $\begin{array}{c}\text { 1979-2018 (40 } \\
\text { Years) }\end{array}$ & Annual Rate of Increment & \\
\hline \multirow{4}{*}{ Onshore } & Mesaieed & 105.65 & +3.46 & +0.086 & +0.08 \\
\hline & Al Khor & 148.58 & -2.76 & -0.069 & -0.05 \\
\hline & Al Ruwais & 139.58 & -4.61 & -0.115 & -0.08 \\
\hline & Dukhan & 125.11 & +2.77 & +0.069 & +0.06 \\
\hline \multirow{4}{*}{ Offshore } & Doha & 145.92 & +1.35 & +0.034 & +0.02 \\
\hline & Ras Laffan & 168.84 & -7.10 & -0.177 & -0.11 \\
\hline & Al Ruwais & 192.23 & -11.57 & -0.289 & -0.15 \\
\hline & Dukhan & 136.24 & -0.23 & -0.006 & 0.00 \\
\hline
\end{tabular}

The AVI, SVI, and MVI can give more highlights on the resource variability. The sites with moderate resources with less variability may be more effective than those sites with higher resources with high variability [71]. The AVI, SVI, and MVI estimated at the select onshore and offshore locations of Qatar are presented in Table 5. The AVI is in the range of $0.32-0.37$ at onshore and offshore locations, which is relatively low, indicating that the variability in annual mean wind power in Qatar is minimum. This is favorable for the installation of power plants in Qatar, considering other design and environmental parameters.

Table 5. Variability indices of wind power densities at onshore and offshore locations.

\begin{tabular}{ccccc}
\hline Region & Locations & Annual Variability Index & $\begin{array}{c}\text { Seasonal Variability } \\
\text { Index }\end{array}$ & $\begin{array}{c}\text { Monthly Variability } \\
\text { Index }\end{array}$ \\
\hline \multirow{3}{*}{ Onshore } & Mesaieed & 0.36 & 0.22 & 1.07 \\
& Al Khor & 0.37 & 0.33 & 0.98 \\
& Al Ruwais & 0.34 & 0.23 & 0.04 \\
\hline \multirow{2}{*}{ Offshore } & Dukhan & 0.32 & 0.37 & 0.94 \\
& Doha & 0.37 & 0.36 & 0.99 \\
& Ras Laffan & 0.37 & 0.34 & 1.00 \\
& Al Ruwais & 0.35 & 0.42 & 0.87 \\
\hline
\end{tabular}




\subsection{Seasonal Mean Wind Power}

The seasonal mean wind power densities and standard deviations during MayOctober (summer) and November-April (winter) have been estimated for the 40 year period (Figure 8). The summer mean wind power is up to $200 \mathrm{~W} / \mathrm{m}^{2}$ in the northernmost region of the EEZ of Qatar, where the standard deviation is up to $280 \mathrm{~W} / \mathrm{m}^{2}$. The winter mean wind power is up to $320 \mathrm{~W} / \mathrm{m}^{2}$ near the north and northeast boundaries of the EEZ of Qatar, where the standard deviation is up to $380 \mathrm{~W} / \mathrm{m}^{2}$. The lowest values during summer and winter are in the southern onshore and offshore areas of Qatar. The winter generates higher wind power than the summer, which is due to the dominance of winter shamal winds. The wind power density during winter is $25-45 \%$ higher than that during summer at onshore locations and $40-60 \%$ at offshore locations. The offshore wind power in Qatar is the highest during winter than summer, which is in contrast with that observed along the coast of Kuwait [35]. This is primarily because of the distinction between the winter shamal and summer shamal winds, in which the latter has more influence on the Peninsula than the Gulf. The coast of Kuwait is in close proximity to the desert winds. Similarly, the southern region (land areas) of Qatar has relatively high wind power during summer than winter.

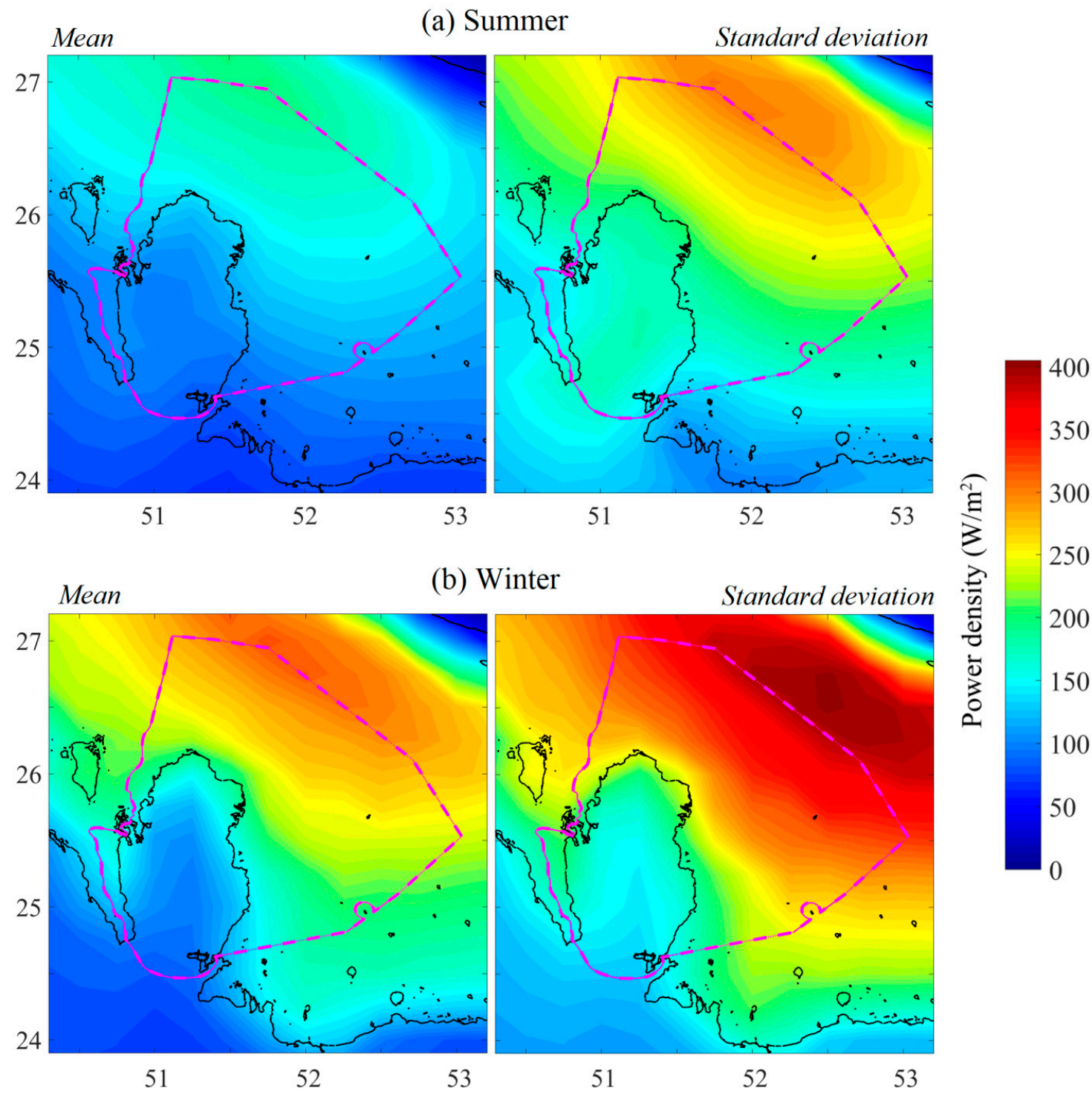

Figure 8. Seasonal mean wind power density and standard deviation for the period 1979-2018 around Qatar during (a) summer and (b) winter. 
Figure 9 shows the seasonal mean wind power at select onshore and offshore locations. The southern onshore areas (Mesaieed and Dukhan) reflect mean wind power densities of $96-104$ and $120-150 \mathrm{~W} / \mathrm{m}^{2}$ during summer and winter, respectively. The north and northeast onshore areas (Al Ruwais and $\mathrm{Al}$ Khor) have mean wind power densities of 122-124 and 154-172 W/ $\mathrm{m}^{2}$ during summer and winter, respectively. The southern offshore region (Dukhan) has mean wind power densities of 105 and $168 \mathrm{~W} / \mathrm{m}^{2}$, while the central offshore region (Doha) reflects mean wind power densities of 121 and $174 \mathrm{~W} / \mathrm{m}^{2}$ during summer and winter, respectively. The northeast and north offshore regions (Ras Laffan and Al Ruwais) have mean wind power densities of 138-194 and 148-226 W/m² during summer and winter, respectively.

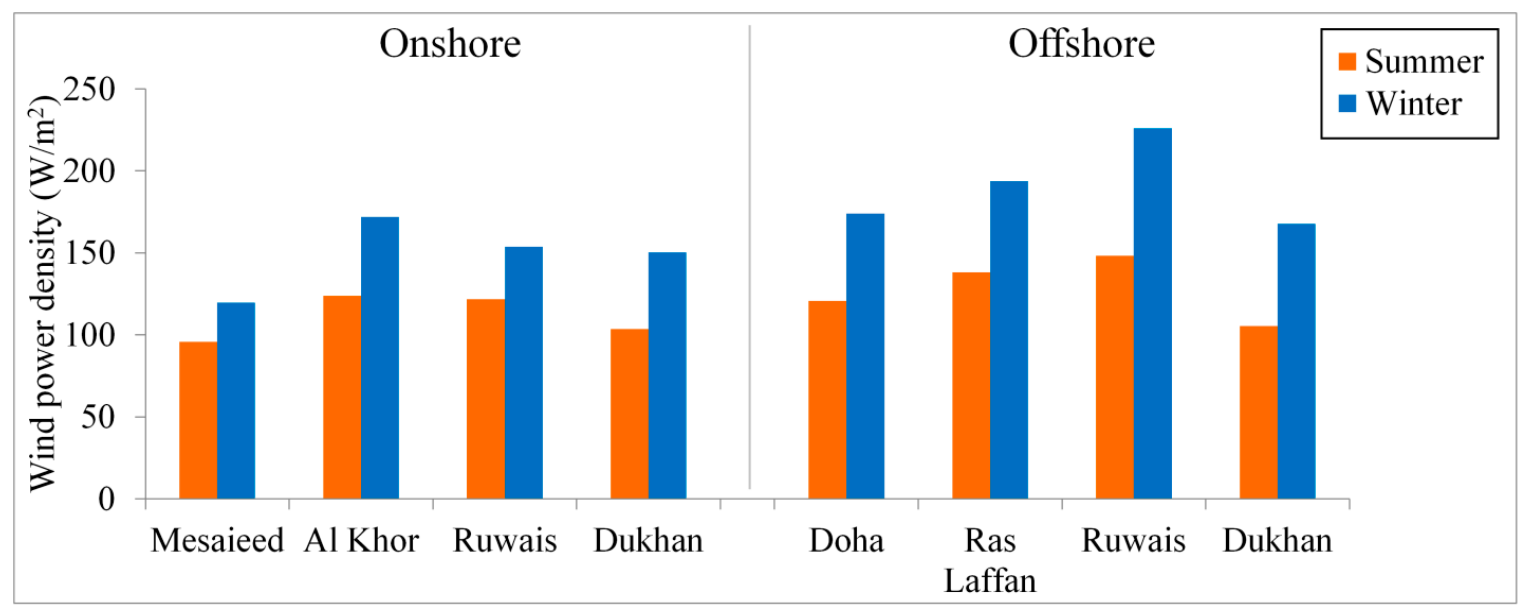

Figure 9. Seasonal mean wind power density for the period 1979-2018 at select onshore and offshore locations.

The SVI at onshore locations is in the range $0.22-0.37$, whereas that at offshore locations is in the range of $0.34-0.46$ (Table 5). These values are relatively low compared to the SVI estimated at the coastal regions of the Black Sea and Sea of Azov [71] because of the relatively low variability in the regional wind systems in the Gulf across the seasons and due to the absence of tropical cyclones.

\subsection{Monthly Mean Wind Power}

The estimated monthly mean wind power densities show that the highest wind power within the EEZ of Qatar (especially offshore) occurred during February, around $400 \mathrm{~W} / \mathrm{m}^{2}$ at the northernmost region (Figure 10). The wind climate studies have already reported that the strongest shamal winds in the region occurred during February, while the number of occurrences was high in January [48,76]. Hence, there is a direct correlation between the shamal magnitudes with the monthly wind power density. The strength and duration of shamal events are consistent in the Gulf, and hence, we can suppose that the estimated high potential during the prevalence of these events is reliable. The high potential continues during the months of January, March, June, and December in descending order. The lowest wind energy potential is found during the months of August and September, when the wind speeds are reasonably low. These are consistent with the observations carried out in the UAE [74].

The site-specific analysis indicates that the monthly mean wind power densities at the onshore locations are the highest during June $\left(162-216 \mathrm{~W} / \mathrm{m}^{2}\right)$, followed by February $\left(144-213 \mathrm{~W} / \mathrm{m}^{2}\right)$, whereas the lowest mean wind power is during September $\left(54-73 \mathrm{~W} / \mathrm{m}^{2}\right)$ (Figure 11). The mean wind power densities at the offshore locations are highest during February $\left(194-282 \mathrm{~W} / \mathrm{m}^{2}\right)$, followed by June $\left(164-247 \mathrm{~W} / \mathrm{m}^{2}\right)$, whereas the lowest mean wind power densities are during September $\left(74-95 \mathrm{~W} / \mathrm{m}^{2}\right)$. The peak mean wind power densities in the onshore and offshore regions are observed to be at $\mathrm{Al} \mathrm{Khor} \mathrm{and}$ Ruwais, respectively. 

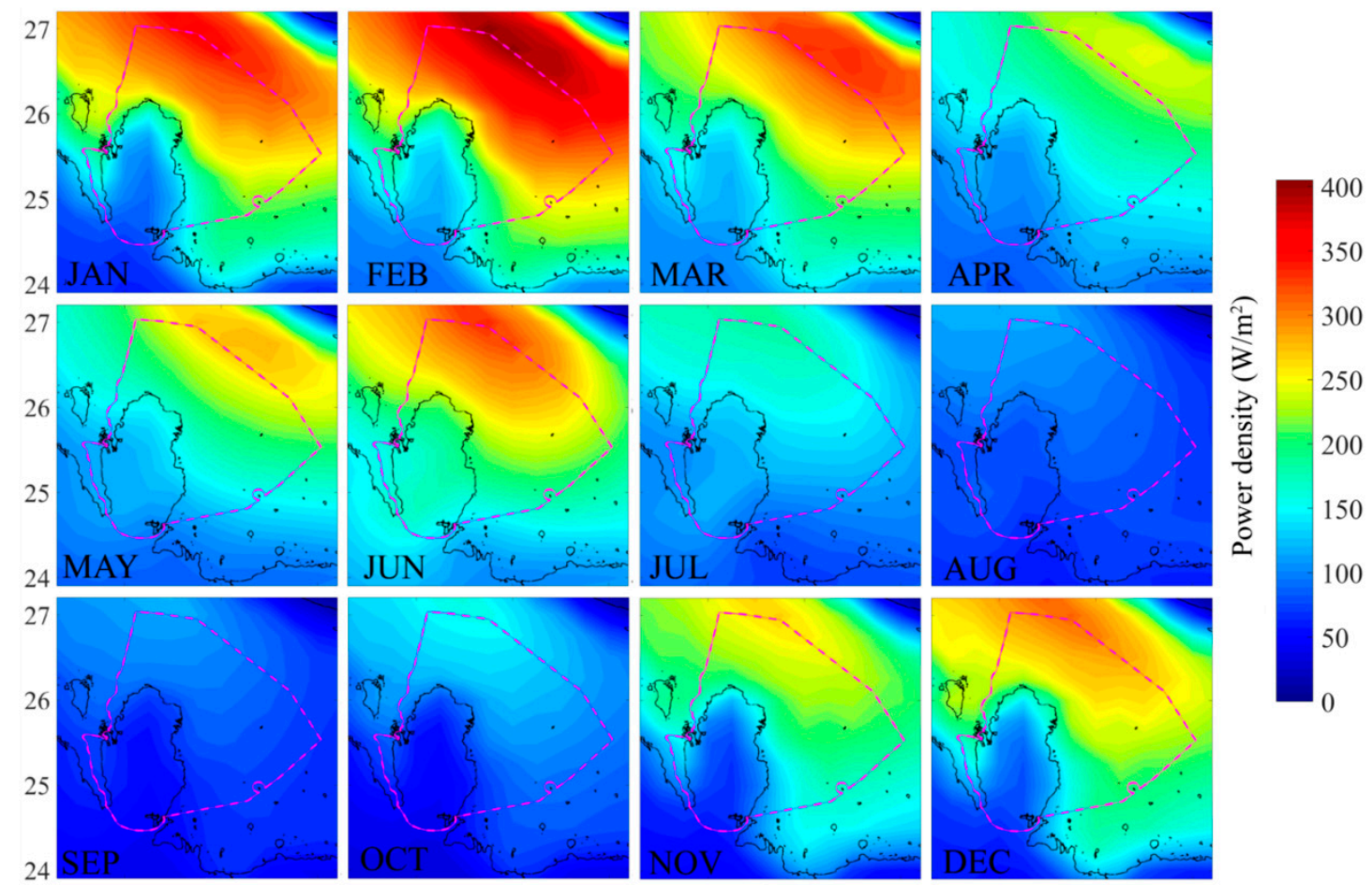

Figure 10. Monthly mean wind power densities during 1979-2018 around Qatar.

(a) Onshore

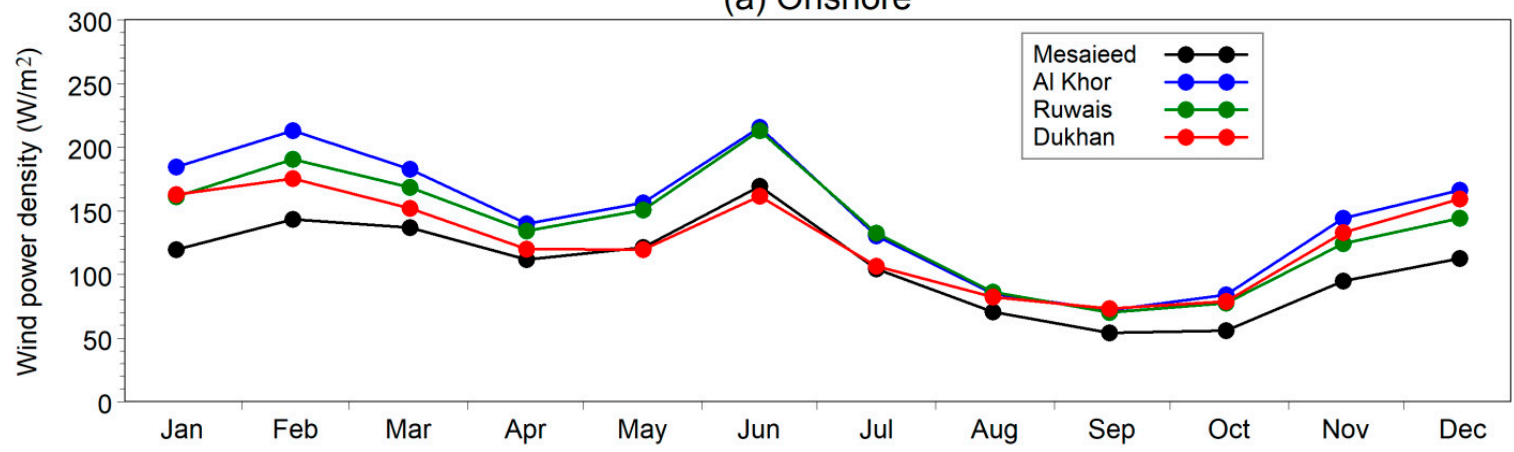

(b) Offshore

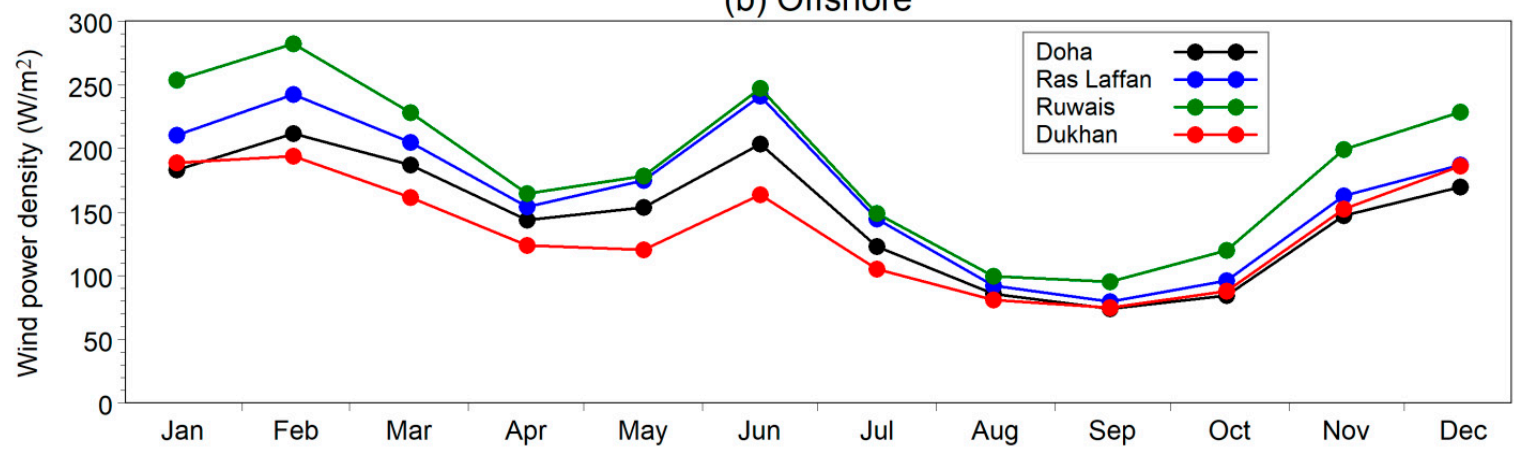

Figure 11. Monthly mean wind power densities during 1979-2018 at select locations: (a) Onshore and (b) offshore.

The MVI at onshore locations is in the range of $0.81-1.07$, whereas that at offshore locations is in the range of $0.87-1.00$ (Table 5). These values are consistent with the MVI estimated along the Black Sea coast of Turkey and in the Sea of Azov but low compared to 
the other coastal regions in the Black Sea [71]. The monthly variability in wind speeds in the enclosed basins is generally higher than that in the open oceans [77].

\section{Conclusions}

Wind energy resource characterization is carried out along the onshore and offshore areas of Qatar, aiming at future exploitation of wind power, in the context of reducing carbon emissions from the conventional energy sectors of the country. The study reveals that the available wind resources are generally moderate with the highest wind power densities along the north and northeast areas, where the 40 year mean wind power is up to $186 \mathrm{~W} / \mathrm{m}^{2}$ and the annual mean wind power is up to $212 \mathrm{~W} / \mathrm{m}^{2}$. Offshore regions of Qatar possess the highest wind power compared to onshore regions. Spatial variability in wind power is apparent due to their proximity to the central Gulf on the north/east and deserts on the south/west. The monthly mean wind power densities are high during December-March (up to $282 \mathrm{~W} / \mathrm{m}^{2}$ ) and June (up to $247 \mathrm{~W} / \mathrm{m}^{2}$ ) due to the influence of winter shamal and summer shamal winds, respectively. Seasonally, the offshore wind power is higher during winter (up to $224 \mathrm{~W} / \mathrm{m}^{2}$ ) than summer $\left(196 \mathrm{~W} / \mathrm{m}^{2}\right)$, which is in contrast with that identified in the Peninsula. The estimated wind power in Qatar is consistent with that estimated in the adjacent Gulf coastal areas, the terrestrial regions of Turkey, the Black Sea, the Sea of Azov, and the Indian coasts. The estimated annual, seasonal, and monthly variability indices indicate that they are within the acceptable limits considering the stability in power generation using wind turbines. Inter-annual variability in wind power prevails in response to the dominant ENSO events. The estimated wind power at the onshore and offshore locations of Qatar has reduced during the strongest El Niño events (e.g., 1982-1983, 1997-1998, and 2015-2016), and increased during the strongest La Niña events (e.g., 1988-1989, 1999-2000, and 2010-2011). Despite the strong inter-annual variability, a weak annual trend is observed in annual mean wind power $\left(-0.27\right.$ to $\left.+0.09 \mathrm{~W} / \mathrm{m}^{2} / \mathrm{y}\right)$. This indicates that a consistent and stable wind power potential is available in Qatar on a long-term perspective.

Author Contributions: Conceptualization, V.M.A., F.N.S. and P.V.; methodology, V.M.A., P.R.S., S.V. and E.M.A.S.A.-A.; software, V.M.A., P.R.S. and S.V.; validation, V.M.A., P.R.S. and P.V.; formal analysis, V.M.A., E.M.A.S.A.-A., F.N.S. and P.V.; investigation, V.M.A. and P.R.S.; resources, P.V. and F.N.S.; data curation, V.M.A., P.R.S. and E.M.A.S.A.-A.; writing-original draft preparation, V.M.A., P.R.S. and S.V.; writing-review and editing, P.V. and V.M.A.; visualization, V.M.A. and P.R.S.; supervision, P.V. and F.N.S.; project administration, P.V.; funding acquisition, P.V. All authors have read and agreed to the published version of the manuscript.

Funding: This research was funded by International Research Co-Fund Collaboration (IRCC) Program of Qatar University, Qatar under the grant number IRCC-2019-002.

Acknowledgments: We thank Hamad Al-Saad Al-Kuwari, Director, Environmental Science Center (ESC), Qatar University for his constant encouragement and support. This work was carried out under the International Research Co-Fund Collaboration (IRCC) Program of QU and NIO (IRCC2019-002), and executed through ORS, QU. The measured wind data were obtained from the Qatar Meteorological Department (QMD) website, which has been manually processed by Mark Edward Chatting, ESC, QU.

Conflicts of Interest: The authors declare no conflict of interest.

\section{References}

1. Zou, C.; Zhao, Q.; Zhang, G.; Xiong, B. Energy revolution: From a fossil energy era to a new energy era. Nat. Gas Ind. B 2016, 3, 1-11. [CrossRef]

2. Abdallah, L.; El-Shennawy, T. Reducing Carbon Dioxide Emissions from Electricity Sector Using Smart Electric Grid Applications. J. Eng. 2013, 2013, 1-8. [CrossRef]

3. Bentley, R. Global oil \& gas depletion: An overview. Energy Policy 2002, 30, 189-205. [CrossRef]

4. Owusu, P.A.; Asumadu-Sarkodie, S. A review of renewable energy sources, sustainability issues and climate change mitigation. Cogent Eng. 2016, 3, 1167990. [CrossRef] 
5. Chaurasiya, P.K.; Warudkar, V.; Ahmed, S. Wind energy development and policy in India: A review. Energy Strat. Rev. 2019, 24, 342-357. [CrossRef]

6. Kucukali, S.; Dinçkal, Ç. Wind energy resource assessment of Izmit in the West Black Sea Coastal Region of Turkey. Renew. Sustain. Energy Rev. 2014, 30, 790-795. [CrossRef]

7. Guo, Q.; Xu, X.; Zhang, K.; Li, Z.; Huang, W.; Mansaray, L.R.; Liu, W.; Wang, X.; Gao, J.; Huang, J. Assessing Global Ocean Wind Energy Resources Using Multiple Satellite Data. Remote Sens. 2018, 10, 100. [CrossRef]

8. Ren, G.; Wan, J.; Liu, J.; Yu, D. Assessing temporal variability of wind resources in China and the spatial correlation of wind power in the selected regions. J. Renew. Sustain. Energy 2020, 12, 13302. [CrossRef]

9. Saha, S.; Moorthi, S.; Pan, H.-L.; Wu, X.; Wang, J.; Nadiga, S.; Tripp, P.; Kistler, R.; Woollen, J.; Behringer, D.; et al. The NCEP Climate Forecast System Reanalysis. Bull. Am. Meteorol. Soc. 2010, 91, 1015-1058. [CrossRef]

10. Saha, S.; Moorthi, S.; Wu, X.; Wang, J.; Nadiga, S.; Tripp, P.; Behringer, D.; Hou, Y.-T.; Chuang, H.-Y.; Iredell, M.; et al. The NCEP Climate Forecast System Version 2. J. Clim. 2014, 27, 2185-2208. [CrossRef]

11. Gelaro, R.; Mccarty, W.; Suárez, M.J.; Todling, R.; Molod, A.; Takacs, L.; Randles, C.A.; Darmenov, A.; Bosilovich, M.G.; Reichle, R.H.; et al. The Modern-Era Retrospective Analysis for Research and Applications, Version 2 (MERRA-2). J. Clim. 2017, 30, 5419-5454. [CrossRef]

12. Uppala, S.M.; Kållberg, P.W.; Simmons, A.J.; Andrae, U.; Bechtold, V.D.C.; Fiorino, M.; Gibson, J.K.; Haseler, J.; Hernandez, A.; Kelly, G.A.; et al. The ERA-40 re-analysis. Q. J. R. Meteorol. Soc. 2005, 131, 2961-3012. [CrossRef]

13. Berrisford, P.; Dee, D.P.; Fielding, M.; Fuentes, M.; Kållberg, P.W.; Kobayashi, S.; Uppala, S. The ERA-Interim Archive. Available online: https://www.ecmwf.int/node/8173 (accessed on 12 October 2020).

14. Hersbach, H.; Bell, B.; Berrisford, P.; Hirahara, S.; Horányi, A.; Muñoz-Sabater, J.; Nicolas, J.; Peubey, C.; Radu, R.; Schepers, D.; et al. The ERA5 global reanalysis. Q. J. R. Meteorol. Soc. 2020, 146, 1999-2049. [CrossRef]

15. Dee, D.P.; Uppala, S.M.; Simmons, A.J.; Berrisford, P.; Poli, P.; Kobayashi, S.; Andrae, U.; Balmaseda, M.A.; Balsamo, G.; Bauer, P.; et al. The ERA-Interim reanalysis: Configuration and performance of the data assimilation system. Q. J. R. Meteorol. Soc. 2011, 137, 553-597. [CrossRef]

16. Kumar, V.S.; Asok, A.B.; George, J.; Amrutha, M.M. Regional Study of Changes in Wind Power in the Indian Shelf Seas over the Last 40 Years. Energies 2020, 13, 2295. [CrossRef]

17. Hoffmann, L.; Günther, G.; Li, D.; Stein, O.; Wu, X.; Griessbach, S.; Heng, Y.; Konopka, P.; Müller, R.; Vogel, B.; et al. From ERA-Interim to ERA5: The considerable impact of ECMWF's next-generation reanalysis on Lagrangian transport simulations. Atmos. Chem. Phys. Discuss. 2019, 19, 3097-3124. [CrossRef]

18. Rivas, M.B.; Stoffelen, A. Characterizing ERA-Interim and ERA5 surface wind biases using ASCAT. Ocean Sci. 2019, 15, 831-852. [CrossRef]

19. Ulazia, A.; Sáenz, J.; Ibarra-Berastegi, G.; González-Rojí, S.J.; Carreno-Madinabeitia, S. Global estimations of wind energy potential considering seasonal air density changes. Energy 2019, 187, 115938. [CrossRef]

20. Ramon, J.; Lledó, L.; Torralba, V.; Soret, A.; Doblas-Reyes, F.J. What global reanalysis best represents near-surface winds? Q. J. R. Meteorol. Soc. 2019, 145, 3236-3251. [CrossRef]

21. Olauson, J. ERA5: The new champion of wind power modelling? Renew. Energy 2018, 126, 322-331. [CrossRef]

22. Thoppil, P.G.; Hogan, P.J. Persian Gulf response to a wintertime shamal wind event. Deep. Sea Res. Part I: Oceanogr. Res. Pap. 2010, 57, 946-955. [CrossRef]

23. Yu, Y.; Notaro, M.; Kalashnikova, O.V.; Garay, M.J. Climatology of summer Shamal wind in the Middle East. J. Geophys. Res. Atmos. 2016, 121, 289-305. [CrossRef]

24. Al Senafi, F.; Anis, A. Shamals and climate variability in the Northern Arabian/Persian Gulf from 1973 to 2012. Int. J. Clim. 2015, 35, 4509-4528. [CrossRef]

25. Perrone, T.J. Winter Shamal in the Persian Gulf; Naval Environmental Prediction Research Facility: Monterey, CA, USA, 1979; p. 180.

26. Kamranzad, B. Persian Gulf zone classification based on the wind and wave climate variability. Ocean Eng. 2018, 169, 604-635. [CrossRef]

27. Eager, R.E.; Raman, S.; Wootten, A.; Westphal, D.L.; Reid, J.S.; Al Mandoos, A. A climatological study of the sea and land breezes in the Arabian Gulf region. J. Geophys. Res. Space Phys. 2008, 113, 113. [CrossRef]

28. Sandeepan, B.; Panchang, V.G.; Nayak, S.; Kumar, K.K.; Kaihatu, J.M. Performance of the WRF Model for Surface Wind Prediction around Qatar. J. Atmospheric Ocean. Technol. 2018, 35, 575-592. [CrossRef]

29. Patlakas, P.; Stathopoulos, C.; Flocas, H.A.; Kalogeri, C.; Kallos, G. Regional Climatic Features of the Arabian Peninsula. Atmosphere 2019, 10, 220. [CrossRef]

30. Balog, I.; Ruti, P.M.; Tobin, I.; Armenio, V.; Vautard, R. A numerical approach for planning offshore wind farms from regional to local scales over the Mediterranean. Renew. Energy 2016, 85, 395-405. [CrossRef]

31. Menendez, M.D.C.R.; García-Díez, M.; Fita, L.; Fernández, J.; Mendez, F.J.; Gutiérrez, J.M. High-resolution sea wind hindcasts over the Mediterranean area. Clim. Dyn. 2013, 42, 1857-1872. [CrossRef]

32. Calaudi, R.; Arena, F.; Badger, M.; Sempreviva, A.M. Offshore Wind Mapping Mediterranean Area Using SAR. Energy Procedia 2013, 40, 38-47. [CrossRef] 
33. Ucar, A.; Balo, F. Evaluation of wind energy potential and electricity generation at six locations in Turkey. Appl. Energy 2009, 86, 1864-1872. [CrossRef]

34. Yip, C.M.A.; Gunturu, U.B.; Stenchikov, G.L. Wind resource characterization in the Arabian Peninsula. Appl. Energy 2016, 164, 826-836. [CrossRef]

35. Al-Nassar, W.; Neelamani, S.; Al-Salem, K.; Al-Dashti, H. Feasibility of offshore wind energy as an alternative source for the state of Kuwait. Energy 2019, 169, 783-796. [CrossRef]

36. Shata, A.A.; Hanitsch, R. The potential of electricity generation on the east coast of Red Sea in Egypt. Renew. Energy 2006, 31, 1597-1615. [CrossRef]

37. Langodan, S.; Viswanadhapalli, Y.; Dasari, H.P.; Knio, O.; Hoteit, I. A high-resolution assessment of wind and wave energy potentials in the Red Sea. Appl. Energy 2016, 181, 244-255. [CrossRef]

38. Al-Salem, K.; Neelamani, S.; Al-Nassar, W. Wind Energy Map of Arabian Gulf. Nat. Resour. 2018, 9, 212-228. [CrossRef]

39. Khonkar, H. Complete Survey of Wind Behavior over the Arabian Gulf. J. King Abdulaziz Univ. Sci. 2009, 20, 31-47. [CrossRef]

40. Ali, A. Wind Meteorology of the Summer Shamal in the Arabian Gulf Region. Master's Thesis, Boston University, Boston, NE, USA, 1994.

41. Rao, P.G.; Hatwar, H.R.; Al-Sulaiti, M.H.; Al-Mulla, A.H. Summer shamals over the Arabian Gulf. Weather 2003, 58, 471-478. [CrossRef]

42. Amirinia, G.; Mafi, S.; Mazaheri, S. Offshore wind resource assessment of Persian Gulf using uncertainty analysis and GIS. Renew. Energy 2017, 113, 915-929. [CrossRef]

43. Alnaser, W.; Almohanadi, A. Wind and solar energy in Qatar. Energy 1990, 15, 931-934. [CrossRef]

44. Marafia, A.-H.; Ashour, H.A. Economics of off-shore/on-shore wind energy systems in Qatar. Renew. Energy 2003, 28, 1953-1963. [CrossRef]

45. Méndez, C.; Bicer, Y. Qatar's Wind Energy Potential with Associated Financial and Environmental Benefits for the Natural Gas Industry. Energies 2019, 12, 3329. [CrossRef]

46. Al-Qaradawi, I.; Abdel-Moati, M.; Al-Yafei, M.A.-A.; Al-Ansari, E.; Al-Maslamani, I.A.; Holm, E.; Al-Shaikh, I.; Mauring, A.; Pinto, P.V.; Abdulmalik, D.; et al. Radioactivity levels in the marine environment along the Exclusive Economic Zone (EEZ) of Qatar. Mar. Pollut. Bull. 2015, 90, 323-329. [CrossRef]

47. Cheng, W.L.; Saleem, A.; Sadr, R. Recent warming trend in the coastal region of Qatar. Theor. Appl. Clim. 2015, 128, 193-205. [CrossRef]

48. Aboobacker, V.M.; Shanas, P.R.; Al-Ansari, E.M.A.S.; Sanil Kumar, V.; Vethamony, P. The maxima in northerly wind speeds and wave heights over the Arabian Sea, the Arabian/Persian Gulf and the Red Sea derived from 40 years of ERA5 data. Clim. Dyn. 2020. (In Press) [CrossRef]

49. Yu, J.; Zhou, T.; Jiang, Z.; Zou, L. Evaluation of Near-Surface Wind Speed Changes during 1979 to 2011 over China Based on Five Reanalysis Datasets. Atmosphere 2019, 10, 804. [CrossRef]

50. Dullaart, J.C.M.; Muis, S.; Bloemendaal, N.; Aerts, J.C.J.H. Advancing global storm surge modelling using the new ERA5 climate reanalysis. Clim. Dyn. 2019, 54, 1007-1021. [CrossRef]

51. Mahmoodi, K.; Ghassemi, H.; Razminia, A. Temporal and spatial characteristics of wave energy in the Persian Gulf based on the ERA5 reanalysis dataset. Energy 2019, 187, 115991. [CrossRef]

52. Tennekes, H. The Logarithmic Wind Profile. J. Atmos. Sci. 1973, 30, 234-238. [CrossRef]

53. Zhou, J.; Erdem, E.; Li, G.; Shi, J. Comprehensive evaluation of wind speed distribution models: A case study for North Dakota sites. Energy Convers. Manag. 2010, 51, 1449-1458. [CrossRef]

54. Genc, A.; Erisoglu, M.; Pekgor, A.; Oturanc, G.; Hepbasli, A.; Ulgen, K. Estimation of Wind Power Potential Using Weibull Distribution. Energy Sources 2005, 27, 809-822. [CrossRef]

55. Chang, T.P. Estimation of wind energy potential using different probability density functions. Appl. Energy 2011, 88, 1848-1856. [CrossRef]

56. Shi, J.; Erdem, E. Estimation of Wind Energy Potential and Prediction of Wind Power; Elsevier BV: Amsterdam, The Netherlands, 2017; pp. 25-49.

57. Chen, Y.; Pillay, P.; Khan, A. PM Wind Generator Topologies. IEEE Trans. Ind. Appl. 2005, 41, 1619-1626. [CrossRef]

58. Li, H.; Chen, Z. Design optimization and site matching of direct-drive permanent magnet wind power generator systems. Renew. Energy 2009, 34, 1175-1184. [CrossRef]

59. Gitano-Briggs, H. Low Speed Wind Turbine Design; IntechOpen: London, UK, 2012.

60. Verde, A.; Lastres, O.; Hernández, G.; Ibáñez, G.; Verea, L.; Sebastian, P. A new method for characterization of small capacity wind turbines with permanent magnet synchronous generator: An experimental study. Heliyon 2018, 4, e00732. [CrossRef]

61. Darwish, A.S.; Shaaban, S.; Marsillac, E.; Mahmood, N.M. A methodology for improving wind energy production in low wind speed regions, with a case study application in Iraq. Comput. Ind. Eng. 2019, 127, 89-102. [CrossRef]

62. Liu, H.; Shi, J.; Qu, X. Empirical investigation on using wind speed volatility to estimate the operation probability and power output of wind turbines. Energy Convers. Manag. 2013, 67, 8-17. [CrossRef]

63. Qu, X.; Shi, J. Bivariate Modeling of Wind Speed and Air Density Distribution for Long-Term Wind Energy Estimation. Int. J. Green Energy 2010, 7, 21-37. [CrossRef]

64. Sen, P.K. Estimates of the Regression Coefficient Based on Kendall's Tau. J. Am. Stat. Assoc. 1968, 63, 1379-1389. [CrossRef] 
65. Hess, A.; Iyer, H.; Malm, W. Linear trend analysis: A comparison of methods. Atmos. Environ. 2001, 35, 5211-5222. [CrossRef]

66. Cosseron, A.; Gunturu, U.B.; Schlosser, C.A. Characterization of the Wind Power Resource in Europe and its Intermittency. Energy Procedia 2013, 40, 58-66. [CrossRef]

67. Cornett, A.M. A global wave energy resource assessment. In Proceedings of the 18th International Offshore and Polar Engineering Conference (ISOPE), International Society of Offshore and Polar Engineers, Vancouver, BC, Canada, 6-11 July 2008.

68. Harrison, R.; Hau, E.; Snel, H. Large Wind Turbines: Design and Economics; Wiley: Chichester, UK, 2000.

69. Zheng, C.; Pan, J.; Li, J.-X. Assessing the China Sea wind energy and wave energy resources from 1988 to 2009. Ocean Eng. 2013, 65, 39-48. [CrossRef]

70. Pantusa, D.; Tomasicchio, G. Large-scale offshore wind production in the Mediterranean Sea. Cogent Eng. 2019, 6, 6. [CrossRef]

71. Rusu, L.; Ganea, D.; Mereuta, E. A joint evaluation of wave and wind energy resources in the Black Sea based on 20-year hindcast information. Energy Explor. Exploit. 2017, 36, 335-351. [CrossRef]

72. Cox, J. Impact of Intermittency: How Wind Variability Could Change the Shape of the British and Irish Electricity Markets; Summary Report; Poyry Energy Ltd.: Oxford, UK, 2009.

73. Knapp, K.R.; Kruk, M.C.; Levinson, D.H.; Diamond, H.J.; Neumann, C.J. The International Best Track Archive for Climate Stewardship (IBTrACS). Bull. Am. Meteorol. Soc. 2010, 91, 363-376. [CrossRef]

74. Naizghi, M.S.; Ouarda, T.B.M.J. Teleconnections and analysis of long-term wind speed variability in the UAE. Int. J. Clim. 2016, 37, 230-248. [CrossRef]

75. Shanas, P.; Aboobacker, V.; AlBarakati, A.M.; Zubier, K.M. Climate driven variability of wind-waves in the Red Sea. Ocean Model. 2017, 119, 105-117. [CrossRef]

76. Aboobacker, V.M.; Shanas, P.R. The climatology of shamals in the Arabian Sea-Part 1: Surface winds. Int. J. Clim. 2018, 38, 4405-4416. [CrossRef]

77. Brano, V.L.; Galanis, G.; Spyrou, C.; Diamantis, D.; Baladima, F.; Koukoula, M.; Kallos, G.B. Assessing the European offshore wind and wave energy resource for combined exploitation. Renew. Energy 2017, 101, 244-264. [CrossRef] 